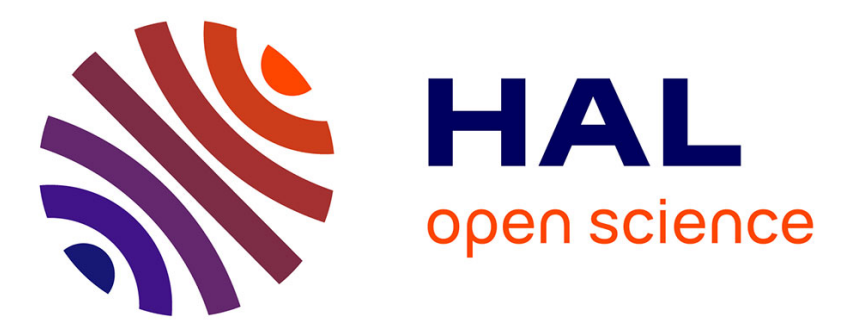

\title{
Extrusive upper crust formation at slow-spreading ridges: Fault steering of lava flows
}

\author{
C. Gini, Javier Escartin, M. Cannat, T. Barreyre
}

\section{To cite this version:}

C. Gini, Javier Escartin, M. Cannat, T. Barreyre. Extrusive upper crust formation at slow-spreading ridges: Fault steering of lava flows. Earth and Planetary Science Letters, 2021, 576, pp.117202. 10.1016/j.epsl.2021.117202 . hal-03362857

\section{HAL Id: hal-03362857 \\ https://hal.science/hal-03362857}

Submitted on 2 Oct 2021

HAL is a multi-disciplinary open access archive for the deposit and dissemination of scientific research documents, whether they are published or not. The documents may come from teaching and research institutions in France or abroad, or from public or private research centers.
L'archive ouverte pluridisciplinaire HAL, est destinée au dépôt et à la diffusion de documents scientifiques de niveau recherche, publiés ou non, émanant des établissements d'enseignement et de recherche français ou étrangers, des laboratoires publics ou privés. 


\section{$1 \quad$ Extrusive upper crust formation at slow-spreading ridges: fault}

\section{steering of lava flows}

$11 *$ Corresponding author: cgini@mun.ca. Now at Memorial University of Newfoundland,

12 St John's, Canada.

\section{Citation:}

C. Gini, J. Escartín, M. Cannat, T. Barreyre, 202I, Extrusive upper crust formation at slow-spreading ridges:

Fault steering of lava flows, Earth and Planetary Science Letters, V. 576, I I 7202, https://doi.org//0.1016/j.epsl.2021.II7202. 
14 The structure of the oceanic upper volcanic crust is less understood at slow-spreading ridges than at faster ones. Its construction is dominated by pillow lavas, reflecting lower

16 effusion rates than those at fast spreading ridges, where sheet and lobate flows are common and flow off-axis while thickening the extrusive volcanic layer. Based on optical and high-resolution bathymetry data from the Lucky Strike segment (Mid-Atlantic Ridge), we document a mode of volcanic emplacement that likely operates at some magmatically robust slow- and ultra-slow spreading ridge segments, in the presence of strong gradients in magma supply. In these settings, sheet flows may efficiently transport melt away from magmatically robust segment centers in the along-axis direction, steered by normal faults, and exploiting along-axis topographic gradients, with limited acrossaxis flow. Surface lineations of sheet lava flows tend to be subparallel to fault scarps and the overall segment orientation, and show whorls, well-developed lava channels with associated levees, and surface fold structures at flow fronts. This mode of lava emplacement transitions away from the segment center to pillow-dominated seafloor near the segment ends, associated often with hummocks and axial volcanic ridges. This results in local lava emplacement due to a melt supply that is lower than at the segment center. We propose that fault-steering of lava flows along-axis, limiting off-axis transport 31 as observed at fast-spreading systems, may be common at both slow- and ultra-slow spreading ridges with significant along-axis changes in magma supply linked to topographic gradients. As a result, the nature and properties of the extrusive volcanic 
34 layer may vary significantly along axis owing to changes in the modes of volcanic

35 emplacement, as transitions from sheet flows to pillow lavas may impact the porosity 36 structure and hence the seismic properties of the extrusive layer in the oceanic upper 37 crust.

Keywords: Mid-ocean ridges; faulting; submarine volcanism; lava flows; morphology.

\section{Highlights}

- Faults steer sheet flows over a few $\mathrm{km}$ along axis, impacting upper crust construction

- Along-axis changes in lava flow morphologies, evidence for melt supply gradients

- Different lava flow morphologies may affect seismic properties of Layer 2A

\section{Introduction}

Volcanic emplacement at the axis of mid-ocean ridges determines the nature, geometry and physical properties of the uppermost extrusive volcanic layer of the oceanic crust. Constraints on this structure have been obtained from geological observations (e.g., submersible studies and ophiolites), and from drilling. At fast-spreading ridges, the volcanic layer is built through surface eruptions emanating from the axial summit trough, lava flows extending off-axis, in addition to dikes that do not reach the surface (Fornari, 1986; Hooft et al., 1996; Soule et al., 2009). Slow-spreading ridges display a wide variety of volcanic morphologies resulting from varying melt supply both at the scale of individual ridge segments and regionally. Based on seafloor observations, it has been 
suggested that pillow lavas are ubiquitous and often emanating from hummocks, small seamounts, or axial volcanic ridges, (Smith and Cann, 1992; Smith and Cann, 1993; Searle et al., 2010; Yeo et al., 2012; Estep et al., 2019), dominating upper crustal construction at slow spreading ridges (see also Figure S6 of Chen et al., 2021). Pillow lavas also suggest flow rates and lateral lava transport that are limited relative to sheeted lava flows (e.g., Griffiths and Fink, 1992; Gregg and Fink, 1995). Sheet flows, which are common at fast spreading ridges, are scarce at slow- and ultra-slow spreading ridges (see Figure S6 in Chen et al., 2021), but they have been reported primarily at large seamounts or central volcanoes (Atwater; 1979; Gracia et al., 1998; Bideau et al., 1998; Bonatti and Harrison, 1988; Edwards et al., 2001; Deschamps et al., 2007; Escartín et al., 2014; Asada et al., 2015), and therefore in areas where magma supply and hence eruption rates are likely elevated. These studies do not report neither the geometry nor the extent and direction of these sheet flows.

At fast spreading ridges, seismic Layer 2A, interpreted to represent the extrusive upper crust, is thinnest at the axis ( $200 \mathrm{~m})$ and thickens away from it (Kent et al., 1994; Hooft et al., 1996). At slow spreading ridges, seismic Layer 2 A may be completely absent along magmatically-starved ridge sections, such as the South-West Indian Ridge (Sauter et al., 2013), or its thickness may exceed that of fast-spreading ridges, being up to $500 \mathrm{~m}$ thick or more at magmatically robust crustal sections (e.g., Hussenoeder et al., 2002; Seher et al., 2010c). Hence, the geometry, nature, and mode of emplacement of the extrusive upper 
crust at slow-spreading ridge sections is both more variable and complex than that of fast-spreading ridges.

Seismic studies at on-axis Atlantic oceanic crust yield Layer 2A thicknesses that typically vary between 350-500 m (Hussenoeder et al., 2002; Peirce et al., 2007; Seher et al., 2010c) and may reach up to $850 \mathrm{~m}$ (Arnulf et al., 2014), with thicknesses up to $1000 \mathrm{~m}$ off-axis (Estep et al., 2019). The overall seismic velocity of Layer 2A, as well as its vertical gradient, also show a temporal evolution attributed to hydrothermal alteration or clogging, pore geometry changes, among other factors (e.g., Wilkens et al., 1991; Grevemeyer et al, 1999; Estep et al., 2019). Layer 2A thickness variations of a few hundreds of m over spatial scales of $\sim 10-20$ km are also well-documented (e.g., Peirce et al., 2007; Seher et al., 2010c; Estep et al., 2019). At the Lucky Strike segment, Layer 2A thickness and upper crust velocity variations have been attributed primarily to a tectonically induced porosity reduction towards the segment ends (Crawford et al., 2010; Seher et al., 1010c), while in other studies and sites variations in seismic properties are attributed to alteration, volcanism, and to interactions among various processes (e.g., Christeson et al., 2019, and references therein).

The Lucky Strike segment is an ideal site to study links between volcanic style (e.g., sheet, lobate and pillow lava flows), and melt supply gradients along the segment, that may be linked to effusion rates (e.g., Griffiths and Fink, 1992; Gregg and Fink, 1995). We analyze high-resolution bathymetry and seafloor imagery, acquired with deep-sea vehicles over several cruises, to quantify the relative importance and along-axis variations of lava 
morphologies, and document directions of surface lava transport, coupled to geophysical data available from the area (shipboard multibeam bathymetry, sonar, and prior seismic reflection studies). We propose a conceptual model of lava emplacement at magmatically robust slow-spreading ridge segments, that takes into account variations in eruption rate and lava transport along-axis. This model is fundamentally different from that proposed for fast-spreading ridges, and has consequences for both the overall structure of the upper volcanic layer, its physical properties (i.e., porosity and thus seismic Layer 2A structure), and its possible variations along-axis linked to melt supply changes that are common at magmatically robust slow-spreading ridge segments. The observations at Lucky Strike that we report here, likely apply to numerous magmatically robust slow- and ultra-slow spreading segments which show either elevated central areas, or central volcanos similar to those at Lucky Strike (e.g., Escartín et al., 2014). This is also supported by the observation of sheet flows at the center of several segments along the Mid-Atlantic Ridge (e.g., Atwater; 1979; Stakes et al., 1984; Gracia et al., 1998) and other slow-spreading ridges (e.g., Asada et al., 2015).

\section{Geological Setting}

The $\sim 70 \mathrm{~km}$ long Lucky Strike ridge segment of the Mid-Atlantic Ridge (MAR) at $\sim 37.25^{\circ} \mathrm{N}$ (Figure 1) is magmatically robust, and influenced by the nearby Azores hotspot to the Northeast (Cannat et al., 1999). Off axis, the older crust shows well-developed ridge-parallel, fault-bounded abyssal hills. At the segment center, a $\sim 20 \mathrm{~km}$ diameter central volcano is underlain by a magma chamber at $\sim 3 \mathrm{~km}$ depth beneath the seafloor 
115 (Singh et al., 2006; Escartín et al., 2014), hosting at its summit one of the largest deep-sea

116 hydrothermal fields along the MAR (Figure $2 \mathrm{~b} h$ and $v$; Langmuir et al., 1997; Humphris

117 et al., 2002; Ondréas et al., 2009; Barreyre et al., 2012; Escartín et al., 2014). The rift valley

118 floor deepens along axis from $\sim 1700 \mathrm{~m}$ depth at the central volcano summit, to $>4000 \mathrm{~m}$

119 at the segment ends (nodal basins), while the axial valley transitions from a narrow, $<2$

$120 \mathrm{~km}$ wide rift zone that dissects the volcano summit (V1 and V2 in Figure 2b), to a broad

121 valley floor at the segment ends. The rift valley lacks axial volcanic ridges in its shallowest

122 section (Figure $2 \mathrm{a}$ and $\mathrm{b}$ ), but these are common at distances $>10 \mathrm{~km}$ from the segment 123 center (Figure $2 \mathrm{c}$ and $\mathrm{d}$, and south of $t$ in $2 \mathrm{~b}$ ).

124 Previous geophysical studies along this segment provide bathymetry, gravity, seismic 125 reflection and refraction data (Cannat et al., 1999; Singh et al., 2006; Seher et al., 2010a;

126 Seher et al., 2010b; Seher et al., 2010c; Crawford et al., 2010; Combier et al., 2015).

127 Geophysical data indicate that the crustal thickness is $\sim 7-8 \mathrm{~km}$ at the segment center, and 128 thins to $<4 \mathrm{~km}$ at its ends (Detrick et al., 1995; Cannat et al., 2008; Crawford et al., 2010;

129 Seher et al., 2010c), likely due to magma being focused to the segment center, and with 130 reduced melt supply to the segment ends (Detrick et al., 1995). Fault patterns also change 131 along-axis, while the rift widens and deepens towards the segment ends (e.g., Cannat et 132 al., 1999; Escartín et al., 2014). Seismic data shows a clear Layer 2A/2B boundary at a two133 way travel time of 0.4-0.5 s below seafloor (Singh et al., 2006; Seher et al., 2010c) and that 134 corresponds to a thickness of $>600 \mathrm{~m}$ (see discussion in Section 7.2). 
136 We benefit from data previously acquired at the Lucky Strike segment during several

137 cruises over more than 20 years. Here we summarize the datasets used, while full

138 information is provided both in the Supplementary Materials and in the references.

139 Shipboard multibeam bathymetry data, gridded at $40 \mathrm{~m}$ and fully covering the ridge 140 segment and adjacent crust, were acquired during the SISMOMAR

141 (https://doi.org/10.17600/5010040) and SUDAÇORES

142 (https:// doi.org/10.17600/98010080) cruises (Figure 1a). High-resolution sidescan sonar

143 data, covering the central part of the rift valley floor (Figure 1b), were acquired with the

144 deep-towed WHOI DSL120 system during the Lustre'96 cruise (http://www.marine-

145 geo.org/tools/entry/KN145-19). Sonar grids are publicly available (Data DOI:

146 10.1594/IEDA/321460) and processing details are given in Escartín et al. (2014). Near-

147 bottom multibeam bathymetry data (Figure 1b) were acquired during 3 cruises:

148 MOMARETO 2006 (https://doi.org/10.17600/6030130), MOMAR'08-Leg 1

149 (https://doi.org/10.17600/8010140) and BATHYLUCK'09

150 (https://doi.org/10.13155/47147). Those surveys were conducted using both the

151 remotely operated vehicle (ROV) VICTOR and the autonomous underwater vehicle

152 (AUV) AsterX. The high-resolution bathymetry grids in Figure $1 \mathrm{~b}$ are publicly available

153 (https:// doi.org/10.17882/80574).

154 Seafloor images were obtained from a) Vertical electronic still images acquired with the

155 WHOI TowCam System (GRAVILUCK'06 cruise, https://doi.org/10.17600/6010110),

156 along several profiles crossing the ridge axis and distributed along-axis; b) Submersible 
157 Nautile video images (Figure 1a; GRAVILUCK'06 cruise), primarily along the ridge axis;

158 c) ROV VICTOR video imagery (Figure 1a; MOMAR2008 and BATHYLUCK'09 cruises, 159 respectively https:// doi.org/10.17600/8010110 and https://doi.org/10.17600/9030040)

160 both along the axis and in adjacent areas; and d) seafloor photomosaics over the Lucky 161 Strike hydrothermal field (Figure 1a; Barreyre et al., 2012), derived from processed black162 and-white vertical images acquired with ROV VICTOR (MOMAR2008 and 163 Bathyluck'09), and publicly available (https://doi.org/10.17882/77449, 164 https://doi.org/10.17882/77405). Photomosaics from ROV surveys (outlines shown in 165 Figure 2a), and from individual camera tows, are also publicly available (see 166 Supplementary materials for details).

\section{Identifying volcanic features to constrain volcanic style}

168 To document and quantify the variations in volcanic style along-axis, we integrate the 169 interpretation of both high-resolution bathymetry, and optical seafloor imagery (Figures 1701 to 4 ), that also cover a wide range of spatial scales (from $\sim 1 \mathrm{~km}$, Figures 2 and 3 , to $<1$

$171 \mathrm{~m}$, Figure 4). Bathymetry, coupled with available sonar imagery (see Escartín et al., 2014)

172 is primarily used to identify volcanic structures at larger scales, such as the limits and 173 structure of lava flows, volcanic ridges, collapse pits associated with fissures, in addition

174 to faults and fissures that are pervasive in the area (Figure 2). Imagery is used to quantify 175 the distribution and abundance of dominant volcanic style along camera tow transects 176 and on photomosaics (Figures 1,2 and 4). As seafloor optical imagery is also oriented and 
scaled, we digitize the orientation of lava flow structures (e.g., lineations on lava flow surfaces) to determine the direction of lava flow transport in the study area.

The bathymetry shows a clear gradient in fine-scale seafloor morphology away from the Lucky Strike segment center. At and around the central Lucky Strike volcano, that shows summital volcanic cones (V1 and V2 in Figure 2), the smooth volcanic seafloor is faulted by a dense network of closely spaced normal faults that bound numerous horsts and grabens (Figure 2a and b). South of the volcanic cone V2 (Figure 2), this smooth volcanic seafloor transitions to hummocky seafloor, typical of slow-spreading ridges, at a distance of $\sim 2.5 \mathrm{~km}$ in the along-axis direction (Figures 2 and 3; Escartín et al., 2014), with welldeveloped axial volcanic ridges further south (Figures 1 and 2). The seafloor relief also reveals the recent, mostly unfaulted along-axis lava flow (Figure 2).

Based on seafloor imagery, we identify and map systematically the distribution of different lava morphologies: sheet flows, lobate flows, and pillows throughout the study area (Figures 2, 3 and 4). In addition to quantifying along-axis variations in the mode of lava flow emplacement, we also a) document the structure of the most recent axial lava channels (Figures 2, 4a, 5), b) determine if the sheet flows are sedimented or unsedimented as a proxy of age, c) study the nature of collapse pits along fissures and grabens (Figure 2) and d) digitize lineations on the sheet flow surface to document the flow direction and the patterns of associated surface melt transport (Figure 6).

\subsection{Along-axis lava flows and faulting}


197 The high-resolution bathymetry in Figures 2 and 3 reveals a young 3-km long sheet flow,

198 which originated at the base of the unrifted southern volcanic cone V2 in Figure 2 at the 199 summit of the central volcano. This lava flow is the youngest identified in the area, it is 200 unfaulted, displays an acoustically reflective surface (Fig. 6 in Escartín et al., 2014), and 201 seafloor observations show that it is visually fresh and unsedimented lavas (Figure 4 a 202 and b; Escartín et al. 2015). The across-flow profiles (Figure 5b) show a 150 m wide 203 channel near its source, with a central part that is lower at the center relative to its edges 204 (1-4 m, p1 in Figure 5b). Distal parts of the flow show instead a domed structure, with a 205 lava flow center higher by a few $m$ (e.g., p2, p4, p6 in Fig. 5b) to >10 m (e.g., p5) with 206 respect to the flow margins. This lava flow was clearly steered by normal fault scarps 207 (Figure $3 \mathrm{a}$ and $5 \mathrm{~b}$ ) and exploited mild topographic gradients that increase from $\sim 1.2^{\circ}$ near 208 the volcanic cone to $\sim 5.2^{\circ}$ further to the south (Figure 5).

The high-resolution bathymetry and seafloor imagery reveal older sheet flows both in the 210 central area (Figures 3a and 4c) or emplaced in low areas among hummocks downrift 211 from the segment center (Figures 2 and 3c). In all cases, the main flow direction appears 212 to be along-axis, and steered by either axis-parallel faults or the flanks of hummocky 213 ridges, which also tend to be elongated along-axis. These sheet flows show a folded 214 surface morphology, with an amplitude of 1-2 $\mathrm{m}$, and wavelengths of $\sim 10-20 \mathrm{~m}$ in along215 flow profiles (Figure 5c). Locally, these structures show evidence of flow off-axis instead 216 of along-axis, that have breached laterally at fault terminations, or covered and flowed 217 over faults (Figure 3). On camera tow imagery, older sheet flows can be identified when 
218 lineations or whorls are apparent through the thin sediment veneer covering them 219 (Figure 4c).

220 Near the young sheet flow source, the depressed flow center shows surface lineations 221 and whorls, that vary in size from a few $\mathrm{m}$ to up to $\sim 20 \mathrm{~m}$ in diameter (Figure $4 \mathrm{a}$ ). Striated 222 lava surfaces within lava flow channels are common along many ridge sections (e.g., East 223 Pacific Rise; Chadwick et al., 1999) and their orientation indicate the lava flow direction. 224 The lineations that we observe at Lucky Strike also seem to be reliable indicators of lava 225 transport; they are visible in photomosaics over lava flows that are well constrained on the bathymetry (Figure 2a and 4), and their distribution could also be observed in detail during a submersible dive following this recent lava flow (see Figure 1a and $4 \mathrm{~b}$ ). These 228 textures (Figure 4) document both high effusion rates and shearing of the lava flow 229 surface during its emplacement (Ballard et al., 1979; Griffith and Fink, 1992; Gregg and 230 Fink, 1995; Lonsdale, 1977). Flow margins that are raised relative to the flow center have 231 hackly lavas that record the break-up of the lava surface at flow edges (Figure 4a; 232 Chadwick et al., 1999; Soule et al., 2005). These volcanic facies are similar to those from 233 lava channels at the EPR, that also show a depressed lava channel likely recording 234 drainage downflow away from the axis during lava emplacement and subsequent 235 deflation (e.g., Chadwick, 2003; Soule et al., 2005).

236 Recent lava flows erupted at Lucky Strike segment center have thus been efficiently 237 steered along-axis by normal fault scarps, and also along the flanks of hummocky ridges, 238 which are aligned along-axis, following gentle along-axis topographic gradients. Lava 
flows can breach laterally and flow short distances off-axis, particularly in areas of low

240 fault scarp relief (for example at $\sim 37.27^{\circ} \mathrm{N}$ in Figure $3 a$ ).

241

242

243

244

\subsection{Lobate and pillow lavas}

Our imagery reveals that both lobate and pillow lavas (Figure $4 \mathrm{~d}$ and e) are present throughout the study area. Lobate lava morphology, which corresponds to local flow rates intermediate between those of sheet flows and pillow lavas (e.g., Griffiths and Fink, 1992), are commonly found at the edges of sheet flows or preserved between branches of jumbled flow. Pillow lavas are found throughout, and particularly making up hummocks and axial volcanic ridges. In sloping areas, pillows are elongated, indicating the direction of lava transport downslope (Figure 4e). Both hummocks and axial volcanic ridges thus build up through pillow lava emplacement as observed elsewhere along the MAR (e.g., Ballard et al., 1975; Yeo et al., 2012).

\subsection{Grabens and collapses}

The high-resolution bathymetry also reveals faults and narrow grabens (10-50 m wide and up to 15-20 $\mathrm{m}$ deep), that are both parallel and oblique to the ridge axis (Figure 3).

Collapse pits, with circular or elongated shapes are clearly aligned along some faults forming narrow grabens (Figure $3 \mathrm{a}$ and $4 \mathrm{f}$ ), that are likely associated with dikes subseafloor subparallel to the ridge axis. Pit diameter is variable and ranges from a few $\mathrm{m}$, to structures that are wider than $50 \mathrm{~m}$, and with depths reaching $\sim 20 \mathrm{~m}$. Imagery and high-resolution bathymetry data show that the edges of these pits lack both elevated rims 
and debris, features expected for structures of an explosive origin (volcanic degassing or

260 hydrothermal explosions). Instead, the morphology is consistent with local gravity 261 collapse, and comparable collapse features associated with dike-induced grabens have 262 been identified both in subaerial volcanic environments (e.g., Okubo and Martel, 1988) 263 and at other planets albeit at much larger scales (e.g., Mege et al., 2003; Davey et al., 2012). Some pits are flat-bottomed, a structure that is consistent with possible lava infill linked to underlying diking along pitted fissures and grabens. Other pits show instead a concave morphology consistent with debris infill due to gravity collapse with no lava infill.

\section{Along-axis lava transport by sheet flows}

High-effusion rate submarine eruptions feed lava flows that follow topographic gradients, transporting lava downslope over distances of hundreds of $\mathrm{m}$ to a few $\mathrm{km}$ (e.g., Gregg and Fornari, 1998). The flow front stops advancing either when lava effusion ceases at the source (volume-limited eruptions) or when lava is efficiently cooled, and the 272 solidification of the crust stops the flow (cooling-limited eruption), as is the case at very short spatial scales (meters) for pillow lavas (e.g., Griffiths and Fink, 1992; Gregg and 274 Fink, 1995; Gregg et al., 1998). Sheet flow lava morphology is thus indicative of relatively 275 high eruption rates, significant eruptive volumes, or both (e.g., Griffiths and Fink, 1992; 276 Gregg and Fink, 1995). This is consistent with the presence of lava whorls (Figure 4 a and 277 c) and well-developed lava channels near the source of the young lava flow (Figures 3 and 4) that emanates from the base of the volcanic cone (V2 in Figure 2) at the summit of 279 the central volcano, and that shows incipient rifting (Escartín et al., 2015). 
The most recent flows identified here flowed southwards (Figure 3), as shown by surface 281 folding away from the lava source (Figure 5c), and by the orientation of lineated lavas, 282 that clearly indicate lava transport direction (e.g., Chadwick et al., 1999). Both the 283 bathymetry and the fault-parallel lineations demonstrate that they are topographically 284 constrained and emplaced against fault scarps, typically $<10 \mathrm{~m}$ in height (Figure 5). 285 Based on the imagery throughout the study area (TowCam tracks and photomosaics, 286 Figures 1, 2 and 4) sheet flows in general show orientation centered at $\sim 5-15^{\circ}$ NE (Figure 287 $6 b)$, consistent with that of fault traces identified in high-resolution sonar data (Escartín 288 et al., 2014) and with the overall orientation of the Lucky Strike ridge segment ( $18^{\circ}$ and $289 \sim 19^{\circ} \mathrm{NE}$ respectively). This agreement suggests widespread lava steering by faults at the 290 center of this segment over at least the last few tens of thousands of years, corresponding 291 to the expected time span required to construct the seafloor in the study area. On Figure 2926 b, the sheet flow lineation orientations along TowCam tracks display more variation 293 than those from lava flows imaged by the photomosaics. This can be the result of local 294 variations in the flow direction within lava flows, which typically flow subparallel to the 295 ridge axis and faults, but instead flow off-axis, in directions oblique to sub-perpendicular 296 to faults, such as those breaching faults and that are visible in the bathymetry (Fig. 3a).

297 While it is not possible to know pre-lava topography in this area, the high-resolution 298 bathymetry constrains a range of plausible thickness along the axial lava flow. Based on 299 the across-axis profiles, we estimate that the thickness of the youngest on-axis flow may 300 vary between a minimum of $\sim 2 \mathrm{~m}$, and a maximum of $\sim 10 \mathrm{~m}$ (profiles $p 3$ and $p 5$ in Figure 
$5 b)$. With an average width of 50-75 $\mathrm{m}$ and a total length of $\sim 2500 \mathrm{~m}$ (Figure 2a), we estimate minimum and maximum lava flow volumes of $\sim 0.25$ and $1.9 \times 10^{6} \mathrm{~m}^{3}$. For comparison, these volumes are 1 to 2 orders of magnitude lower than the 2005-2006 axial eruption at $9^{\circ} \mathrm{N}$ along the EPR (Soule et al., 2007), or than other documented eruptions along the EPR, Juan de Fuca, and Gorda Ridges (Clague et al., 2017; see also compilation by Gregg and Fornari, 1998).

\section{Along-axis variations in mode of lava emplacement}

Seafloor imagery acquired on- and across-axis documents both the relative abundance of different lava morphologies, and their variation along-axis (Figures 1 and 6a). Sheet flows are the dominant mode of lava emplacement at the center of the study area, accounting for $\sim 35 \%$ of characterized seafloor, locally exceeding $>40 \%$ (Figure $6 a$ ). At the northern and southern ends of the segment, in contrast, sheet flows account for only $\sim 10-20 \%$ of identified seafloor textures, while pillow lavas are most abundant ( $>40 \%$; Figure $6 a)$. Lobate flows, representing effusion rates intermediate between those of sheet flows and pillows, are present throughout, but are less abundant ( $20 \%$ or less), and show no systematic along-axis variation (Figure 6a).

The towed camera photographed sedimented seafloor off-axis (Figure 6a), where the morphology of the underlying seafloor cannot be determined unequivocally. Fissures in these sedimented areas may reveal the underlying volcanic seafloor, under a thin sediment veneer (see supplementary material Figure S1b). In most cases the sediment 
cover is thin, and efficiently covers flat sheet flows, while it cannot fully cover pillows

322 and lobate lavas. This suggests that completely sedimented areas are likely sheet flows 323 with a thin sedimented veneer, and therefore the relative abundance of sheet flows may

324 be somewhat higher than indicated by the positively identified lava textures, particularly 325 at the center of the segment (Figure 6a, S1b).

326 While the overall abundance of sheet flows increases towards the segment center, tracks 327 CT09 and CT05 in Figure 6a, across the summit of the central volcano, show a local 328 decrease in the abundance of sheet flows instead. The summit of the central volcano 329 shows a complex recent history of volcanic emplacement that includes two volcanic cones 330 (V1 and V2 in Figure 2) at two different stages of rifting (e.g., Escartín et al., 2015), leading 331 to the formation of a depression hosting a fossil lava lake (Ondréas et al., 2009). These 332 volcanic cones are built up by local lava emplacement dominated by pillows, but also 333 sourcing and feeding the sheet flows which emanated from their base (Figure 2 and 3).

\section{7. Discussion}

\subsection{Sheet flows and along-axis fault steering of lava flows at slow-spreading ridges}

336 The eruption of pillow lavas which build both hummocks and axial volcanic ridges, is 337 considered to be the main mechanism of upper volcanic crust construction at slow338 spreading mid-ocean ridges. Our results suggest that along segments that are both magmatically robust and with associated along-axis variations in melt supply to the

340 seafloor, this upper volcanic crust construction may be locally controlled by the 
interaction of faults that steer lava flows along the ridge axis. This is also consistent with

342 geological observations at the several magmatic ridge segments, particularly along the 343 MAR (e.g., Ballard et al., 1979; Atwater 1979; Crane and Ballard, 1981; Gracia et al., 1998;

344 Stakes et al., 1984), that report sheet flows at their segment centers reflecting focusing of 345 melt, and enhanced delivery of lava to the seafloor, at these locations (e.g., Atwater, 1979;

346 Gracia et al., 1998; Bideau et al., 1998).

347 The sheet flow abundance that we determine optically $(\sim 30-40 \%$ at the segment center,

348 Figure 6) is much higher than that reported for some slow-spreading sites (e.g., 10-15\% 349 at the AMAR segment, Atwater, 1979; or $\sim 10 \%$ at the Marianas $17^{\circ} \mathrm{S}$ segment, Asada et 350 al., 2015) or fast ones (20\% at EPR at $9^{\circ} 50^{\prime} \mathrm{N}$, Kurras et al., 2000) and commensurable to 351 the abundances reported along other areas of the EPR ( 30-50\%, White et al., 2002) or at 352 Axial Caldera along the Juan de Fuca Ridge ( $40 \%$, Embley et al., 1990), sites that are 353 extremely active magmatically. While there is no information on the orientation of 354 lineated flows at other slow-spreading ridges, these sheet flows are commonly reported 355 in low-lying areas at the feet of axial volcanic ridges and fault scarps (e.g., Stakes et al., 356 1984), as it is the case for the Lucky Strike flows (Figure 2).

357 Along-axis fault-control on the mode of lava emplacement at Lucky Strike is also 358 consistent with a recent lava eruption identified along the Reykjanes Ridge (Crane et al., 359 1997), that is emplaced along a system of faults defining a graben, and that extends $\sim 3$ $360 \mathrm{~km}$ along-axis, a similar length to that of the axial flow at Lucky Strike (Figure 3a). This 361 type of fault-controlled lava flow is also observed in terrestrial rift systems, mainly in the 
AFAR area and along the East African Rift (Figure 7). As in the case of Lucky Strike and other slow- and ultra-slow volcanic ridge segments, volcanoes often develop at the center of rift zones, and are densely dissected by parallel fissures, faults, and grabens (e.g., Dumont et al., 2019). For example, the recent lava flow SE of Hayli Gub volcano, shown in Figure 7a, flowed $>15 \mathrm{~km}$ along the center of the axial graben (Barberi and Varet, 1971), while the several flows along the Dabbahu-Manda Hararo rift extend $>10 \mathrm{~km}$, also alonggraben (Figure $7 \mathrm{~b}$ ). The interaction of lava flows with fault scarps, that is also observed at the East Pacific Rise (e.g., Escartín et al., 2007), probably results in the partial or complete burial of some tectonic features, and results in a significant underestimate of tectonic strain based on fault distribution and scarp height (e.g., Escartín et al., 2007; Medynski et al., 2016; Dumont et al., 2019).

\subsection{Changing modes of lava emplacement and Layer $2 A$ properties}

The bathymetry and seafloor images (Figures 2, 3, 4 and 6) clearly show an along-axis transition from sheet- to pillow-dominated lava emplacement between the segment center and areas off to the North and South. This transition coincides with a larger-scale morphological change from smooth and regularly faulted terrain, to a rougher one dominated by hummocks and volcanic ridges. This likely reflects a gradual decrease in eruption rates (e.g., Gregg and Fink, 1995) away from the segment center, where the crust is thicker and the overall melt supply is inferred to be higher than at the segment ends. Off-axis camera tow images also suggest that these along-axis variations are persistent over time (Figure 6). 
Differences in lava morphology (sheet flows vs. pillow lavas) probably result in a volcanic upper crust that differs depending on the dominant lava type, that may impact the seismic properties of Layer 2A (Figure 8a). Sheet flows efficiently fill fissures, depressions, and other small-scale topographic features. Successive sheet flows will therefore show a two-dimensional structure, with sub-horizontal interfaces (cracks), and a smooth, planar seafloor (Figure 8c left) as observed at the Lucky Strike segment (Figure $2 \mathrm{a}$ and b). In contrast, an upper crust dominated by the emplacement of pillow lavas will be associated with a three-dimensional porosity structure (sub-spherical spaces between pillows) and significant topographic relief (no lateral lava transport, local emplacement; Figure $8 \mathrm{c}$ right). Global seismic studies do not reveal a significant difference in overall Layer 2A seismic velocity across spreading rates and sites, possibly due to numerous other local factors that also impact seismic velocity, such as alteration, faulting, fissuring, hydrothermal activity, etc. (see Christeson et al., 2019, and references therein). Furthermore, lava flows, in particular lobate ones, may show significant voids due to lava drain and collapse of the volcanic surface. Site-specific studies are thus required to correlate local variations of seismic properties with other observables.

Figure $8 \mathrm{c}$ presents a simplified sketch of two end-member models and a transitional one, depicting the internal structure and nature of the volcanic upper crust and of the possible impact on Layer 2A seismic properties. These models may apply to different positions along the Lucky Strike segment and may be valid for other slow- and ultra-slow spreading ridge segments with locally high melt supply. For example, crack shape and 
orientation have a strong control on seismic velocity, as well-aligned, elongated planar cracks efficiently slow-down wave propagation in directions perpendicular to them relative to units with equant porosity. At the same time, seismic velocity is also controlled by overall porosity. Hence, while an upper crust formed by successive sheet flows may have lower porosity and hence higher seismic velocities than a 'regular' ridge section with pillow lavas, the anisotropy associated with the sub-horizontal sheet flows (which may be assimilated to elongated cracks) may instead lower these seismic velocities in the vertical direction, perpendicular to flows (cracks). The presence of abundant subhorizontal lava flows may also increase the internal seismic reflectivity of these units. The competing effect of porosity and crack shape on upper crust seismic structure may thus depend on the detailed internal structure of the upper crust that is formed through complex interaction of different modes of lava emplacement with faulting (Figure 8c).

Figure 8a shows the two-way travel time (TTWT) difference between the seafloor and the Layer2A/2B boundary identified along the axis of the Lucky Strike central volcano (Seher et al., 2010c). While the data shows significant scatter, there is a significant increase of $\sim 0.1 \mathrm{~km} / \mathrm{s}$ of the TWTT $\sim 15 \mathrm{~km}$ from the segment center (Figure 8a and b), and both towards the North and South. This TWTT may be attributed to an increase in Layer 2A thickness away from the ridge, to a reduction of the overall seismic velocity of this layer, or to a combination of both. Seismic velocity studies indicate an anomalously thick layer 2A associated with the central volcano ( $750-800 \mathrm{~m})$, as well as anomalously low seismic velocities $(\sim 2 \mathrm{~km} / \mathrm{s})$ that are attributed to the intense faulting (Arnulf et al., 2014). While 
this excess Layer 2A thickness reported by Arnulf et al. (2014) is consistent with the presence of the central volcano, the TWTT increase away from the axis seems inconsistent with the focusing of melt to the segment center, where enhanced volcanism is expected, and the reduced melt supply at the segment ends where a thinner Layer 2A may develop instead. Therefore, this TTWT difference variation may be related to the change in the volcanic style instead of the Layer 2A thickness. With the increasing abundance of pillow

431 lavas away from the segment center, that are associated with hummocky terrain and 432 volcanic ridges, Layer 2A along the Lucky Strike segment may show lower overall 433 seismic velocities, consistent with this TWTT difference increase (blue dashed lines in 434 Figure 8a).

Acknowledgements: This paper benefitted from datasets acquired during numerous cruises 437 (Lustre'96, Graviluck'06, Bathyluck'08 and Bathyluck'09) and we thank the work of crews, 438 officers, technical staff and science parties. We also benefitted from discussions with D. Fornari 439 and A. Soule in the early stages of this project. This paper was improved after thorough and 440 constructive reviews by J. Karson and B. Chadwick, in addition to the Editor's comments. Cruises 441 were supported by NSF, USA (Lustre'96), and by the French Ministry of Research (rest of the 442 cruises). The data analyses and research were supported by CNRS (JE, MC), U. of Bergen (TB), 443 and both IPGP and U. Paris Diderot (CG). 


\section{References}

Arnulf, A.F., Harding, A.J., Kent, G.M., Singh, S.C., and Crawford, W.C., 2014. Constraints on the shallow velocity structure of the Lucky Strike Volcano, MidAtlantic Ridge, from downward continued multichannel streamer data. J. Geophys. Res. Solid Earth, v. 119, no. 2, p. 1119-1144, doi: 10.1002/2013JB010500.

Asada, M., Yoshikawa, S., Mochizuki, N., Nogi, Y., and Okino, K., 2015, Examination of Volcanic Activity: AUV and Submersible Observations of Fine-Scale Lava Flow Distributions Along the Southern Mariana Trough Spreading Axis, in Ishibashi, J., Okino, K., and Sunamura, M. eds., Subseafloor Biosphere Linked to Hydrothermal Systems, Springer Japan, Tokyo, p. 469-478.

Atwater, T., 1979, Constraints from the Famous area concerning the structure of the oceanic section, in p. 33-42.

Ballard, R.D., Bryan, W.B., Heirtzler, J.R., Keller, G., Moore, J.G., van Andel, T., 1975. Manned submersible observations in the FAMOUS Area: Mid-Atlantic Ridge. Science, v. 190, 103-108.

Ballard, R.D., Holcomb, R.T., van Andel, T.H., 1979. The Galapagos rift at $86^{\circ} \mathrm{W} 2$. Sheet flows, collapse pits, and lava lakes of the rift valley. J. Geophys. Res. 84, 5407-5422.

Barberi, F., and Varet, J., 1971. The Erta Ale volcanic range (Danakil Depression, Northern Afar, Ethiopia). Bulletin Volcanologique, v. 34, no. 4, p. 848-917. 
Barreyre, T., Escartín, J., Garcia, R., Cannat, M., Mittelstaedt, E., and Prados, R., 2012. Structure, temporal evolution, and heat flux estimates from the Lucky Strike deep-sea hydrothermal field derived from seafloor image mosaics. Geochem. Geophys. Geosyst., 13, Q04007, doi:10.1029/2011GC003990.

Bideau, D., Hékinian, R., Sichler, B., Gràcia, E., Bollinger, C., Constantin, M., and Guivel, C., 1998, Contrasting volcanic-tectonic processes during the past 2 Ma on the MidAtlantic Ridge: submersible mapping, petrological and magnetic results at lat. $34^{\circ} 52^{\prime} \mathrm{N}$ and $33^{\circ} 55^{\prime} \mathrm{N}$ : Marine Geophysical Researches, v. 20, p. 425-458.

Bonatti, E., Harrison, C.G.A., 1988. Eruption styles of basalt in oceanic spreading ridges and seamounts: Effect of magma temperature and viscosity. J. Geophys. Res. 93, 2967. https:// doi.org/10.1029/JB093iB04p02967

Cannat, M., Briais, A., Deplus, C., Escartín, J., Georgen, J., Lin, J., Mercouriev, S., Meyzen, C., Muller, M., Pouliquen, G., Rabain, A., and Da Silva, P., 1999. Mid-Atlantic RidgeAzores hotspot interactions: Along-axis migration of a hotspot-derived event of enhanced magmatism 10 to 4 Ma ago. Earth and Planetary Science Letters, v. 173, no. 3, doi: 10.1016/S0012-821X(99)00234-4.

Cannat, M., Sauter, D., Bezos, A., Meyzen, C., Humler, E., and Le Rigoleur, M., 2008. Spreading rate, spreading obliquity, and melt supply at the ultraslow spreading Southwest Indian Ridge. Geochem. Geophys. Geosyst., 9, Q04002, doi:10.1029/2007GC001676. 
Chadwick William W., J., 2003, Quantitative constraints on the growth of submarine lava pillars from a monitoring instrument that was caught in a lava flow: Journal of Geophysical Research, v. 108, no. B11, p. 2534, doi:10.1029/2003JB002422.

Chadwick, W.W., Gregg, T.K.P., Embley, R.W., 1999. Submarine lineated sheet flows: a unique lava morphology formed on subsiding lava ponds. Bull. of Volcanol. 61, 194206. https:// doi.org/10.1007/s004450050271

Chen, J., Cannat, M., Tao, C., Sauter, D., and Munschy, M., 2021. 780 thousand years of upper-crustal construction at a melt-rich segment of the ultraslow spreading Southwest Indian Ridge $50^{\circ} 28^{\prime}$ E, J. Geophys. Res. Solid Earth, doi: 10.1029/2021JB022152.

Christeson, G.L., Goff, J.A., and Reece, R.S., 2019, Synthesis of Oceanic Crustal Structure From Two-Dimensional Seismic Profiles: Reviews of Geophysics, v. 57, no. 2, p. 504529, doi: 10.1029/2019RG000641.

Clague, D., Paduan, J., Caress, D., Chadwick, W., Le Saout, M., Dreyer, B., Portner, R., 2017. High-Resolution AUV Mapping and Targeted ROV Observations of Three Historical Lava Flows at Axial Seamount. Oceanography 30. https:/ / doi.org/10.5670/oceanog.2017.426

Combier, V., Seher, T., Singh, S.C., Crawford, W.C., Cannat, M., Escartín, J., and Dusunur, D., 2015. Three-dimensional geometry of axial magma chamber roof and faults at 

no. 8, doi: 10.1002/2015JB012365.

504

505

506

507

Crane, K., and Ballard, R.D., 1981, Volcanics and structure of the FAMOUS narrowgate rift: evidence for cyclic evolution: AMAR 1: Journal of Geophysical Research, v. 86, no. B6, p. 5112-5124.

Crane, K., Johnson, L., Appelgate, B., Nishimura, C., Buck, R., Jones, C., Vogt, P., and Kos'yan, R., 1997, Volcanic and Seismic Swarm Events on the Reykjanes Ridge and Their Similarities to Events on Iceland: Results of a Rapid Response Mission: Marine Geophysical Research, v. 19, no. 4, p. 319-338, doi: 10.1023/A:1004298425881.

Crawford, W.C., Singh, S.C., Seher, T., Combier, V., Dusunur, D., Cannat, M., Rona, P., Devey, C.W., Dyment, J., and Murton, B., 2010. Crustal structure, magma chamber and faulting beneath the Lucky Strike hydrothermal fields, in Diversity of Hydrothermal Systems on Slow Spreading Ocean Ridges, AGU, Washington DC, p. 113-132.

Davey, S., Ernst, R. et Samson, C., 2011. « Radiating graben-fissure system in Imdr Regio, Venus ». Communication lors de la conférence : Advances in Earth Sciences Research Conference (Ottawa, ON, Canada, Mar. 25-27, 2011). 
Detrick, R.S., Needham, H.D., Renard, V., 1995. Gravity anomalies and crustal thickness variations along the Mid-Atlantic ridge between $33^{\circ} \mathrm{N}$ and $40^{\circ} \mathrm{N}$. J. Geophys. Res. $100,3767-3787$.

Deschamps, A., Tivey, M., Embley, R.W., Chadwick, W.W., 2007. Quantitative study of the deformation at Southern Explorer Ridge using high-resolution bathymetric data. Earth and Planetary Science Letters, 259, 1-17. https:/ / doi.org/10.1016/j.epsl.2007.04.007

Dumont, S., Klinger, Y., Socquet, A., Escartín, J., Grandin, R., Jacques, E., Medynski, S., and Doubre, C., 2019. Rifting Processes at a Continent-Ocean Transition Rift Revealed by Fault Analysis: Example of Dabbahu-Manda-Hararo Rift (Ethiopia). Tectonics, v. 38, no. 1, p. 190-214, doi: 10.1029/2018TC005141.

Edwards, M.H., Kurras, G.J., Tolstoy, M., Bohnenstiehl, D., Coakley, B.J., and Cochran, J.R., 2001. Evidence of recent volcanic activity on the ultra-slow Gakkel ridge: Nature, v. 409, p. 808-812. https:/ / doi.org/10.1038/35057258.

Embley, R.W., Murphy, K.M., and Fox, C.G., 1990, High-resolution studies of the summit of Axial Volcano: Journal of Geophysical Research, v. 95, no. B8, p. 12785, doi: 10.1029/JB095iB08p12785.

Escartín, J., Soule, S.A., Fornari, D.J., Tivey, M.A., Schouten, H., and Perfit, M.R., 2007. Interplay between faults and lava flows in construction of the upper oceanic crust: 

10.1029/2006GC001399.

540

Escartín, J., Soule, S.A., Cannat, M., Fornari, D.J., Düşünür, D., and Garcia, R., 2014. Lucky Strike seamount: Implications for the emplacement and rifting of segment-centered volcanoes at slow spreading mid-ocean ridges. Geochem. Geophys. Geosyst., v. 15, no. 11, p. 4157-4179, doi: 10.1002/2014GC005477

Escartín, J., Barreyre, T., Cannat, M., Garcia, R., Gracias, N., Deschamps, A., Salocchi, A., Sarradin, P.-M., Ballu, V., 2015. Hydrothermal activity along the slow-spreading Lucky Strike ridge segment (Mid-Atlantic Ridge): Distribution, heatflux, and geological controls. Earth and Planetary Science Letters, 431, 173-185. https:/ / doi.org/10.1016/j.epsl.2015.09.025

Estep, J., Reece, R., Kardell, D.A., Christeson, G.L., and Carlson, R.L., 2019. Seismic Layer 2A: Evolution and Thickness From 0- to 70-Ma Crust in the Slow-Intermediate Spreading South Atlantic. J. Geophys. Res. Solid Earth, v. 124, no. 8, p. 7633-7651, doi: 10.1029/2019JB017302

Fornari, D.J., 1986. Submarine lava tubes and channels. Bull. of Volcanol., v. 48, p. 291298.

Gràcia, E., Parson, L.M., Bideau, D., and Hekinian, R., 1998, Volcano-tectonic variability along segments of the Mid-Atlantic Ridge between Azores platform and Hayes 

(R. A. Mills \& K. Harrison, Eds.): Geological Society, London, Special Publications, v. 148, no. 1, p. 1-15, doi: 10.1144/GSL.SP.1998.148.01.01.

560

561

Gregg, T.K.P., Fink, J.H., 1995. Quantification of submarine lava-flow morphology through analog experiments. Geology 23, 73. https://doi.org/10.1130/00917613(1995)023<0073:QOSLFM>2.3.CO;2

Gregg, T.K.P., Fink, J.H., Griffiths, R.W., 1998. Formation of multiple fold generations on lava flow surfaces: Influence of strain rate, cooling rate, and lava composition. J. Volcanol. Geotherm. Res. 80, 281-292.

Gregg, T.K.P., Fornari, D.J., 1998. Long submarine lava flows: Observations and results from numerical modeling. J. Geophys. Res. Solid Earth 103, 27517-27531. https:/ / doi.org/https:/ / doi.org/10.1029/98JB02465

Grevemeyer, I., Kaul, N., Villinger, H., Weigel, W., 1999. Hydrothermal activity and the evolution of the seismic properties of upper oceanic crust. J. Geophys. Res. 104, 50695079, doi:10.1029/1998JB900096

Griffiths, R.W., Fink, J.H., 1992. Solidification and morphology of submarine lavas: A dependence on extrusion rate. J. Geophys. Res. 97, 19729. https:/ / doi.org/10.1029/92JB01594 
Hooft, E.E.E., Schouten, H., and Detrick, R.S., 1996. Constraining crustal emplacement processes from the variation in Layer 2A thickness at the East Pacific Rise. Earth and Planetary Science Letters, v. 142, p. 289-309, https://doi.org/10.1016/0012$821 \times(96) 00101-x$

Humphris, S.E., Fornari, D.J., Scheirer, D.S., German, C.R., and Parson, L.M., 2002. Geotectonic setting of hydrothermal activity on the summit of Lucky Strike seamount $\left(37^{\circ} 17^{\prime}\right.$ N, Mid-Atlantic Ridge). Geochem. Geophys. Geosyst., v. 3, no. 8, doi: 10.1029/2001GC000284.

Hussenoeder, S.A., Kent, G.M., and Detrick, R.S., 2002. Upper crustal seismic structure of the slow-spreading Mid-Atlantic Ridge, $35^{\circ} \mathrm{N}$ : Constraints on volcanic emplacement processes. J. Geophys. Res., v. 107, no. B8, doi: 10.1029/2001JB001691

Kent, G.M., Harding, A.J., Orcutt, J.A., Detrick, R.S., Mutter, J.C., and Buhl, P., 1994. Uniform accretion of oceanic crust south of the Garrett transform at $14^{\circ} 15^{\prime} \mathrm{S}$ on the East Pacific Rise. J. Geophys. Res., v. 99, no. B5, p. 9097-9116.

Kurras, G.J., RFornari, D.J., Edwards, M.H., Perfit, M.R., and Smith, M.C., 2000, Volcanic morphology of the East Pacific Rise Crest 9 $49^{\prime}-52^{\prime}$ : Implications for volcanic emplacement processes at fast-spreading mid-ocean ridges: Marine Geophysical Researches, v. 21, p. 23-41. 
593 Langmuir, C., Humphris, S., Fornari, D., Van Dover, C., Von Damm, K., Tivey, M.K., 594 Colodner, D., Charlou, J. -1., Desonie, D., Wilson, C., Fouquet, Y., Klinkhammer, G., 595 and Bougault, H., 1997. Hydrothermal vents near a mantle hot spot: the Lucky Strike 596 vent field at $37^{\circ} \mathrm{N}$ on the Mid-Atlantic Ridge. Earth and Planetary Science Letters, v. 597 148, p. 69-91, https:/ / doi.org/10.1016/S0012-821X(97)00027-7

598 Lonsdale, P., 1977. Abyssal pahoehoe with lava coils at the Galapagos rift. Geology 5, 599 147-152.

600

601

602

603

604

605

606

607

608

609

610

Medynski, S., Pik, R., Burnard, P., Dumont, S., Grandin, R., Williams, A., Blard, P.-H., Schimmelpfennig, I., Vye-Brown, C., France, L., Ayalew, D., Benedetti, L., and Yirgu, G., 2016. Magmatic cycles pace tectonic and morphological expression of rifting (Afar depression, Ethiopia). Earth and Planetary Science Letters, v. 446, p. 77-88, doi: 10.1016/j.eps1.2016.04.014

Mège, D., Cook, A. C., Garel, E., Lagabrielle, Y., and Cormier, M.-H., 2003. Volcanic rifting at Martian grabens. J. Geophys. Res., 108, 5044, doi:10.1029/2002JE001852, E5.

Okubo, C.H., Martel, S.J., 1998. Pit crater formation on Kilauea volcano, Hawaii. J. Volcanol. Geotherm. Res. 86, 1-18.

Ondréas, H., Cannat, M., Fouquet, Y., Normand, A., Sarradin, P.-M., Sarrazin, J., 2009. 

Q02006, doi:10.1029/2008GC002171.

613 Peirce, C., Sinha, M., Topping, S., and Gill, C., 2007. Morphology and genesis of slow614 spreading ridges - seabed scattering and seismic imaging within the oceanic crust. 615 Geophysical Journal International, v. 168, p. 59-89, doi: 10.1111/j.1365$616 \quad$ 246X.2006.03223.x

617 Sauter, D., Cannat, M., Rouméjon, S. et al., 2013. Continuous exhumation of mantle618 derived rocks at the Southwest Indian Ridge for 11 million years. Nature Geosci. 6, 314-320. https://doi.org/10.1038/ngeo1771

Searle, R.C., Murton, B.J., Achenbach, K., LeBas, T., Tivey, M., Yeo, I., Cormier, M.H., Carlut, J., Ferreira, P., Mallows, C., Morris, K., Scroth, N., van Calsteren, P., and Walters, C., 2010. Structure and development of an axial volcanic ridge: Mid-Atlantic Ridge, $45^{\circ}$ N. Earth and Planetary Science Letters, v. 209, p. 228-241,

Seher, T., Crawford, W.C., Singh, S.C., Cannat, M., Combier, V., and Dusunur, D., 2010a. Crustal velocity structure of the Lucky Strike segment of the Mid-Atlantic Ridge at 37 N from seismic refraction measurements. J. Geophys. Res., v. 115, p. B03103, doi:10.1029/2009JB006650. 
629 Seher, T., Singh, S.C., Crawford, W.C., and Escartín, J., 2010b. Upper crustal velocity 630 structure beneath the central Lucky Strike Segment from seismic refraction 631 measurements. Geochem. Geophys. Geosyst., v. 11, no. 5, p. Q05001, doi: 632 10.1029/2009GC002894.

633 Seher, T., Crawford, W.C., Singh, S.C., and Cannat, M., 2010c. Seismic layer 2A variations 634 in the Lucky Strike segment at the Mid-Atlantic Ridge from reflection measurements. 635

Singh, S., Crawford, W., Carton, H., Seher, T., Combier, V., Cannat, M., Canales, J. P., J. Geophys. Res., v. 115, p. B07107, doi: 10.1029/2009JB006783 365, p. $707-715$.

644 Soule, S.A., Fornari, D.J., Perfit, M.R., Tivey, M.A., Ridley, W.I., Schouten, H., 2005. 645 Channelized lava flows at the East Pacific Rise crest $9^{\circ}-10^{\circ} \mathrm{N}$ : The importance of offaxis lava transport in developing the architecture of young oceanic crust. Geochem. Geophys. Geosyst., 6, https://doi.org/10.1029/2005GC000912 
Soule, S.A., Fornari, D.J., Perfit, M.R., Rubin, K.H., 2007. New insights into mid-ocean ridge volcanic processes from the 2005-2006 eruption of the East Pacific Rise, $9^{\circ} 46^{\prime} \mathrm{N}-$ 956'N. Geology 35, 1079. https:/ / doi.org/10.1130/G23924A.1

Soule, S.A., Escartín, J., and Fornari, D.J., 2009. A record of eruption and intrusion at a fast-spreading ridge axis: the axial summit trough of the East Pacific Rise $9^{\circ}-10^{\circ} \mathrm{N}$. Geochem. Geophys. Geosyst., v. 10, no. 10, p. Q10T07, doi:10.1029/2008GC002354.

Stakes, D.S., Shervais, J.W., and Hopson, C.A., 1984, The volcanic-tectonic cycle of the FAMOUS and AMAR valleys, Mid-Atlantic Ridge $\left(36^{\circ} 47^{\prime} \mathrm{N}\right)$ : Evidence from basalt glass and phenocryst compositional variations for a steady state magma chamber beneath the valley midsections, AMAR3: Journal of Geophysical Research, v. 89, no. B8, p. 6995-7028.

Wilkens, R. H., Fryer, G. J., and Karsten, J., 1991. Evolution of porosity and seismic structure of upper oceanic crust: Importance of aspect ratios. J. Geophys. Res., 96( B11), 17981- 17995, doi:10.1029/91JB01454

White, S.M., Haymon, R.M., Fornari, D.J., Perfit, M.R., and Macdonald, K.C., 2002, Correlation between volcanic and tectonic segmentation of fast-spreading ridges: evidence from volcanic structures and lava flow morphology on the East Pacific Rise at $9^{\circ}-10^{\circ} \mathrm{N}$ : Journal of Geophysical Research, v. 107, no. B8, p. 10.1029/2001JB000571. 
666 Yeo, I., Searle, R.C., Achenbach, K.L., Le Bas, T.P., Murton, B.J., 2012. Eruptive 667 hummocks: Building blocks of the upper ocean crust. Geology 40, 91-94. $668 \quad$ https://doi.org/10.1130/G31892.1 


\section{Captions and figures}

671 Figure 1. a) Shipboard bathymetry of the Lucky Strike ridge segment, showing camera tow tracks 672 (numbered red lines), Nautile submersible tracks (black lines) and VICTOR remotely operated 673 vehicle tracks (blue lines). Numbered black circles indicate the location of images in Figure 4. b) 674 Near-bottom multibeam bathymetry surveys ( $\sim \mathrm{m}$ resolution) underlain by ship multibeam 675 bathymetry (with transparency). The blue line shows the extent of the Lustre'96 DSL120 deep676 towed sonar survey (Humphris et al., 2002; Escartin et al., 2014). Black boxes represent the 677 location of Figure 2. See text and Supplementary Materials for details on cruises and datasets.

678 Figure 2. Shaded bathymetry (left) and slope (right) maps of the central section of the Lucky Strike 679 segment ( $a$ and $b$ ), and of the rift valley floor towards the end of the segment ( $c$ and $d$ ). See Figure 6801 for locations. At the segment center ( $a$ and $b$ ), faults dissect two volcanic cones (V1 and V2) and 681 crosscut a flat seafloor that is formed primarily by the accumulation of sheet flows (sf and pink 682 shade in panel $b$; see text). This flat seafloor transitions to hummocks (h in panel b) and axial 683 volcanic ridges towards the south, which are also faulted and fissured. This transition is indicated 684 by the arrow labelled $\mathrm{t}$. At the segment end ( $c$ and $d$ ) the seafloor is fully covered by hummocks, 685 variably fissured and faulted. Hydrothermal deposits (h, orange transparency) are present at the 686 center of the volcanic cones, and vents are indicated by red dots. Collapse pits are indicated by $c$. 687 White and red boxes show the locations of Figure $3 a, b$ and $c$, and the blue outlines in a) indicate 688 the extent of seafloor optical photomosaics $(\mathrm{pm})$.

689 Figure 3. a) Shaded high-resolution bathymetry ( $1 \mathrm{~m}$ resolution) of the Lucky Strike axis along 690 the southern flank of the central volcano (location of panels $a, b$ and $c$ is shown in Figure 2b) 
691 showing the most recent axial lava flow ( $a$ and $b$ ), and older (more sedimented) lava flows (c), and 692 associated volcanic structures. b) Detail of the terminal portion of the axial lava flow. c) Lava 693 flows, showing folded textures, emplaced at the base of hummock mounds. Labels correspond to 694 location of images in Figure 4 and profiles $(p)$ in Figure 5. Blue lines indicate location of 695 topographic profiles in Figure 5.

Figure 4. Examples of lava textures, tectonic and volcanic structures from seafloor imagery along the Lucky Strike segment. a) Photomosaic (ROV imagery) of the axial lava flow head, showing the main channel with lineations (yellow lines) and whorls (yellow dots at their centers), the brokenup lavas (jumbled or hackly lavas) at the flow edge (dashed white line), and the bounding fault scarp. b) Oblique view of axial lava flow (Nautile video grab, dive\#1624). c) Partially sedimented and faulted off-axis sheet flow with lava coils, adjacent to a fault scarp to the right (OTUS photomosaic). d) Lobate flows (CT\#7). e) Pillow lavas on the flanks of a volcanic ridge, elongated in the downhill flow direction (CT\#4). f) Collapse pit along a dike-related graben system (OTUS photomosaic, Bathyluck'09). Locations of images are shown in Figs. $1(d, e)$ and $3(a,-c, f)$.

Figure 5. a) Profile along the center of the youngest axial flow, showing the location of the acrossflow profiles in b) and two of the detailed along-flow profiles in c). b) Across-flow profiles show the change in morphology, from a wide flow with a collapsed central channel ( $p 1)$ to an inflated flow, bound by fault scarps (p5-p6). c) Detailed along-flow profiles showing the amplitude (1-2 m) and wavelength ( 10-20 $\mathrm{m}$ ) of the folds in the surface of the lava flow (see Figure 3). The location of profile pc is shown in Figure 3c. 
711 Figure 6. a) Along-axis bathymetry profile (top) and relative abundance of lava flow types along 712 camera tow tracks CT01 through CT10 (locations shown in Figure 1a). b) Orientation of lineations 713 identified both at camera tow tracks (CT\#) and the photomosaics (PM) at the center of the Lucky

714 Strike segment, and fault orientations digitized from side-scan sonar data (Escartín et al., 2014).

715 For reference, the plot also shows the mean orientations of sheet flow lineations, faults, and the 716 Lucky Strike segment (LS), indicated by inverted triangles, and the standard deviation when 717 available (horizontal lines).

718 Figure 7. Recent lava flows, shaded in red, steered by fault scarps from the Afar region, a) along 719 the rift extending SE of Hayli Gub volcano, and terminating and spreading at the sedimented Afrera Lake plain and b) along the Northern Manda-Hararo Rift, SE of Dabahu volcano. Satellite imagery: (CCNES/Airbus provided by Google Maps (accessed March 2021).

Figure 8. Geological interpretation of the upper oceanic crust, Layer 2A, at the Lucky Strike segment. a) Along-axis variations in Layer 2A two-way travel time (TWTT) difference between the seafloor and the Layer 2A/2B reflector (modified from Seher et al., 2010c). Towed camera transect numbers are indicated as TowCam track number). The red dashed line corresponds to the average TWTT difference for the segment center (sheet flow dominated), and the blue dashed lines highlight the gradients towards the $N$ and $S$ with increasing TWTT difference. b) Shaded bathymetric map from Seher et al. (2010c). c) Sketches showing the structure and construction of the upper oceanic crust at a slow-spreading ridge with high melt supply, from segment center to segment ends. Left: Sheet flow dominated seafloor, with interpreted high seismic velocity and low porosity. Middle: transitional crust between the end-members, characterized by a mix of sheet 
732 flows deviated from the axis and ponding around axial volcanic ridges, and pillows accreting as

733 axial volcanic ridges. Right: Axial volcanic ridge dominated seafloor, with feeding dikes. High

734 porosity between pillows and may be associated lower seismic velocity. Colored arrows for each

735 model are located along the axis ( $a$ and $b$ ).

736

737

738

Figure 1

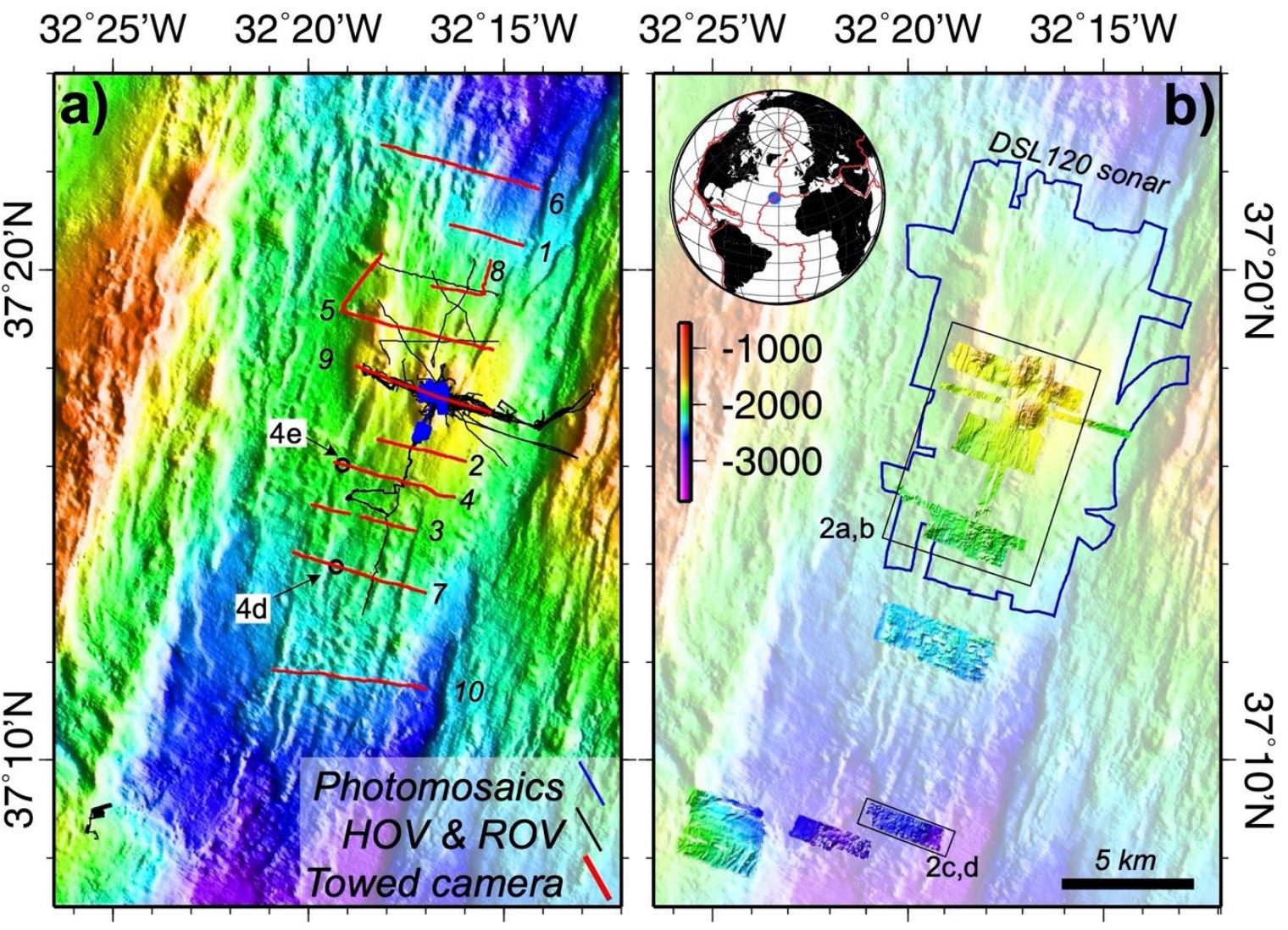


$740 \quad$ Figure 2

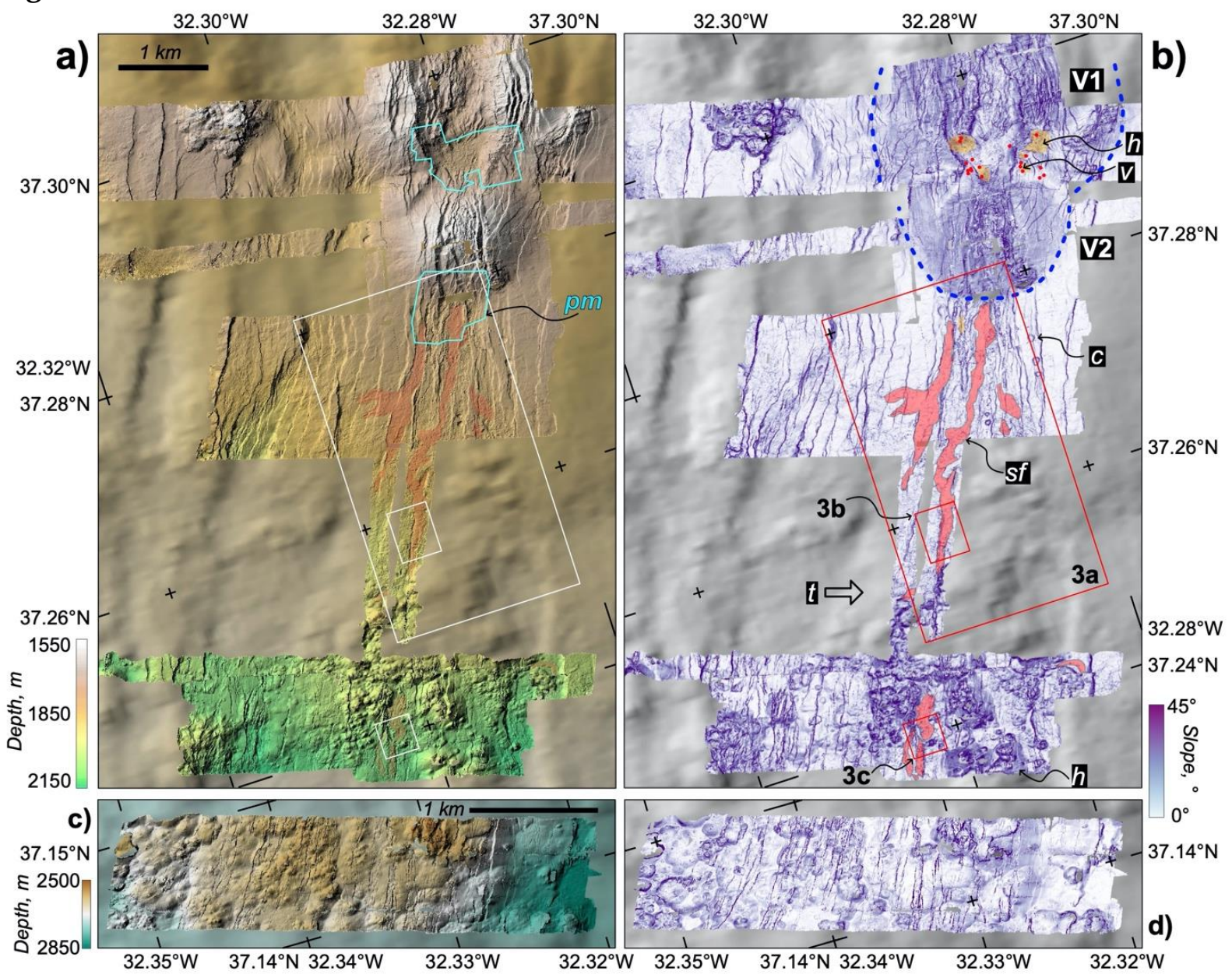


$742 \quad$ Figure 3

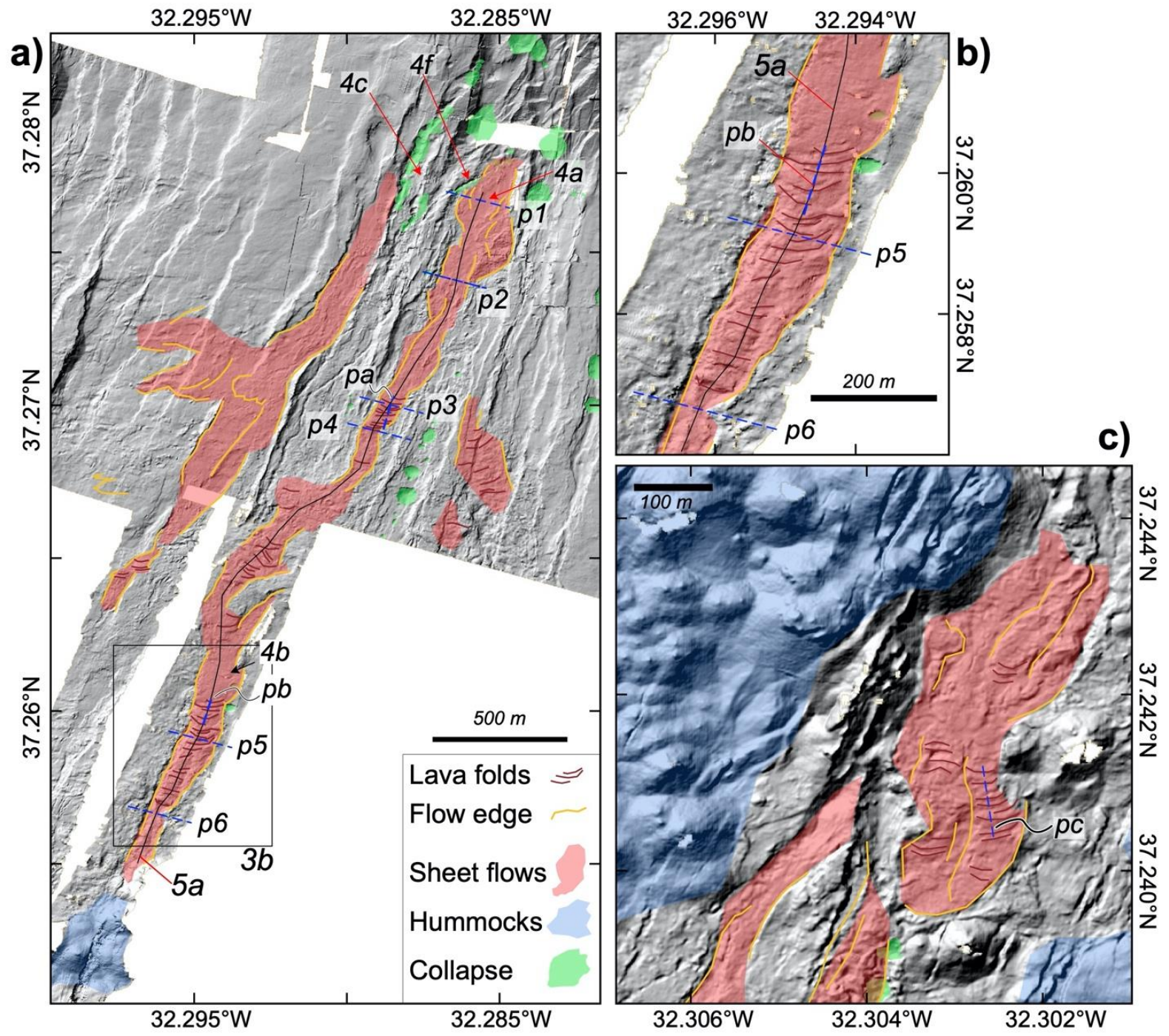


$744 \quad$ Figure 4
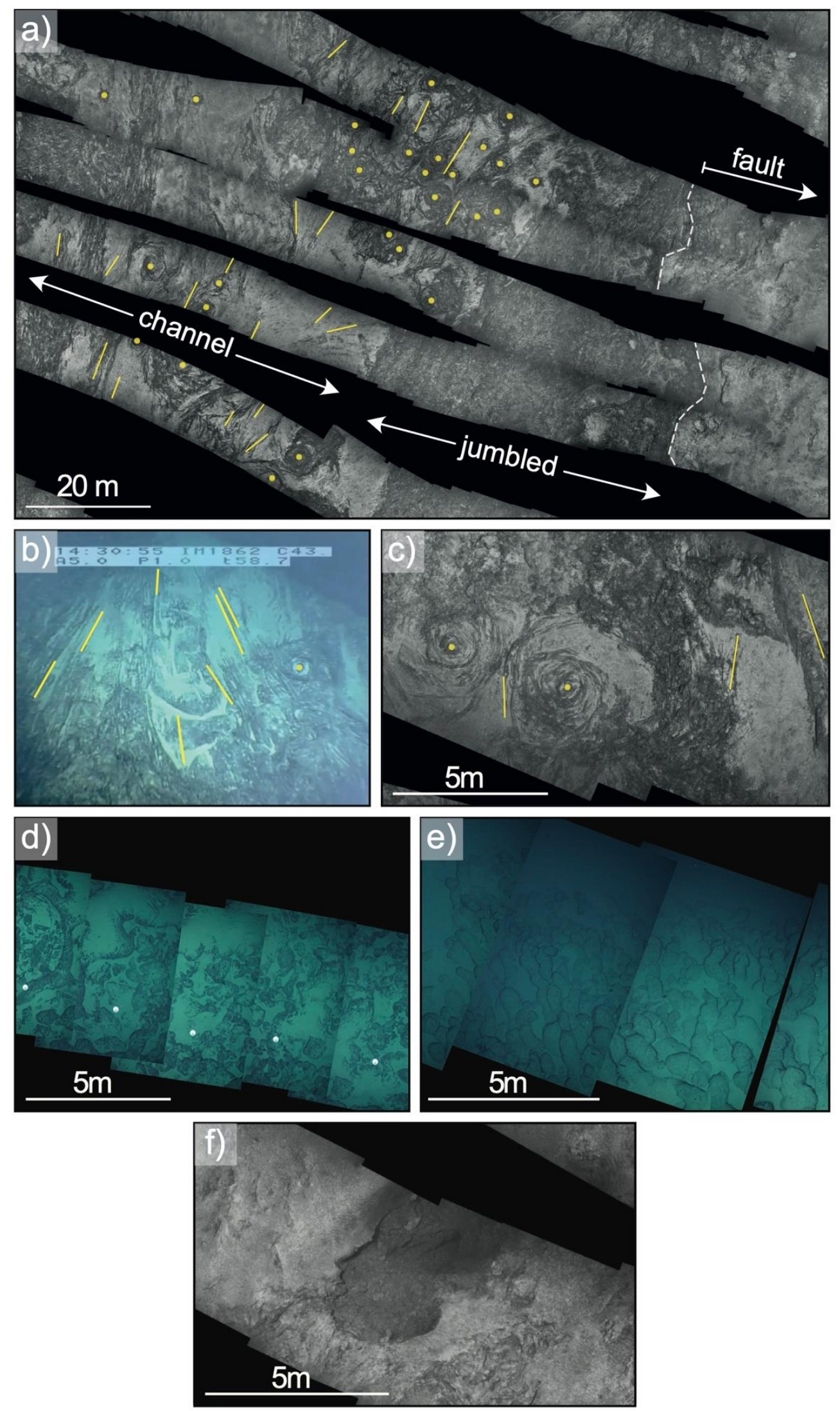
$745 \quad$ Figure 5

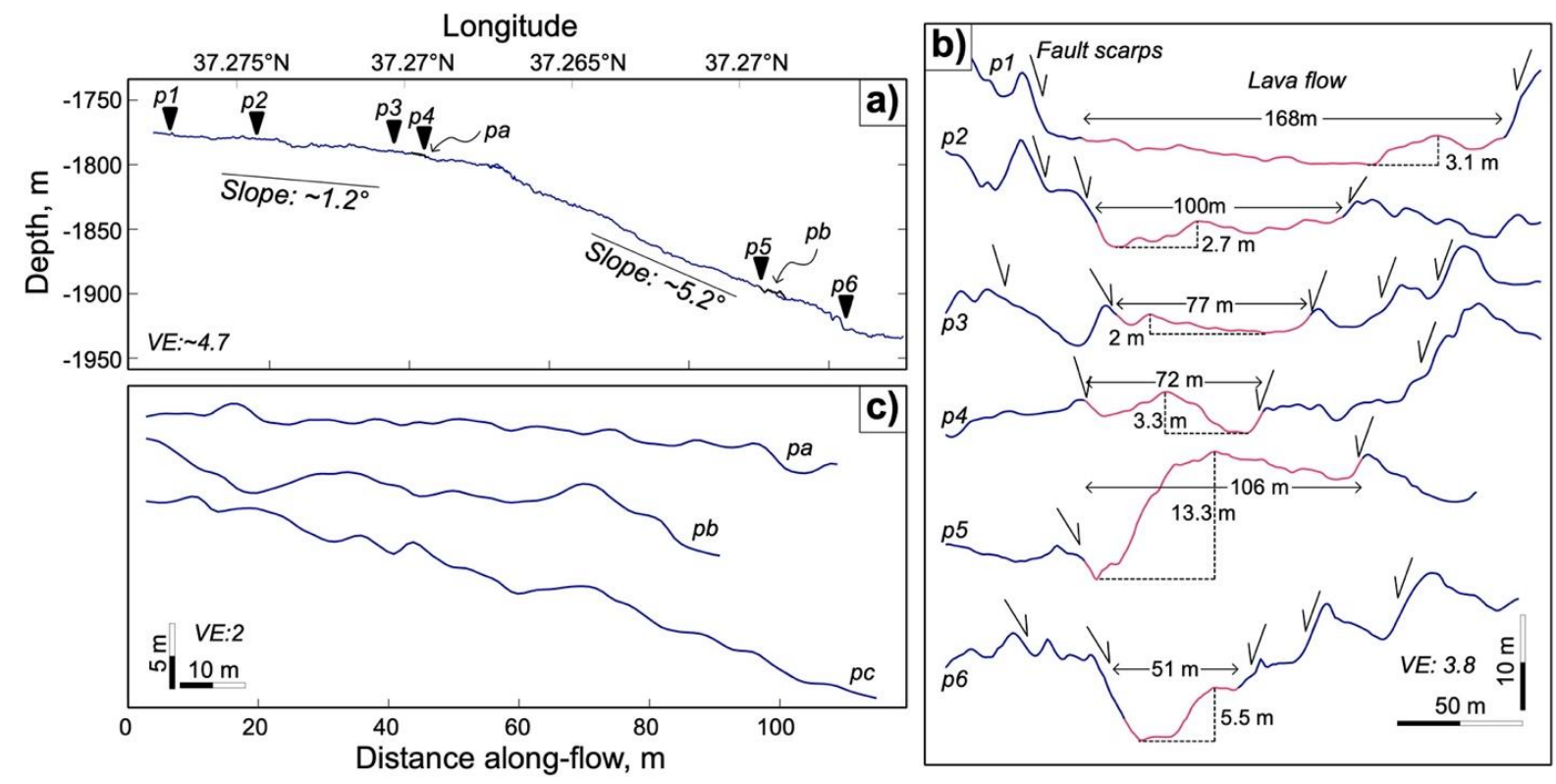


a)

Distance from segment center, $\mathrm{km}$
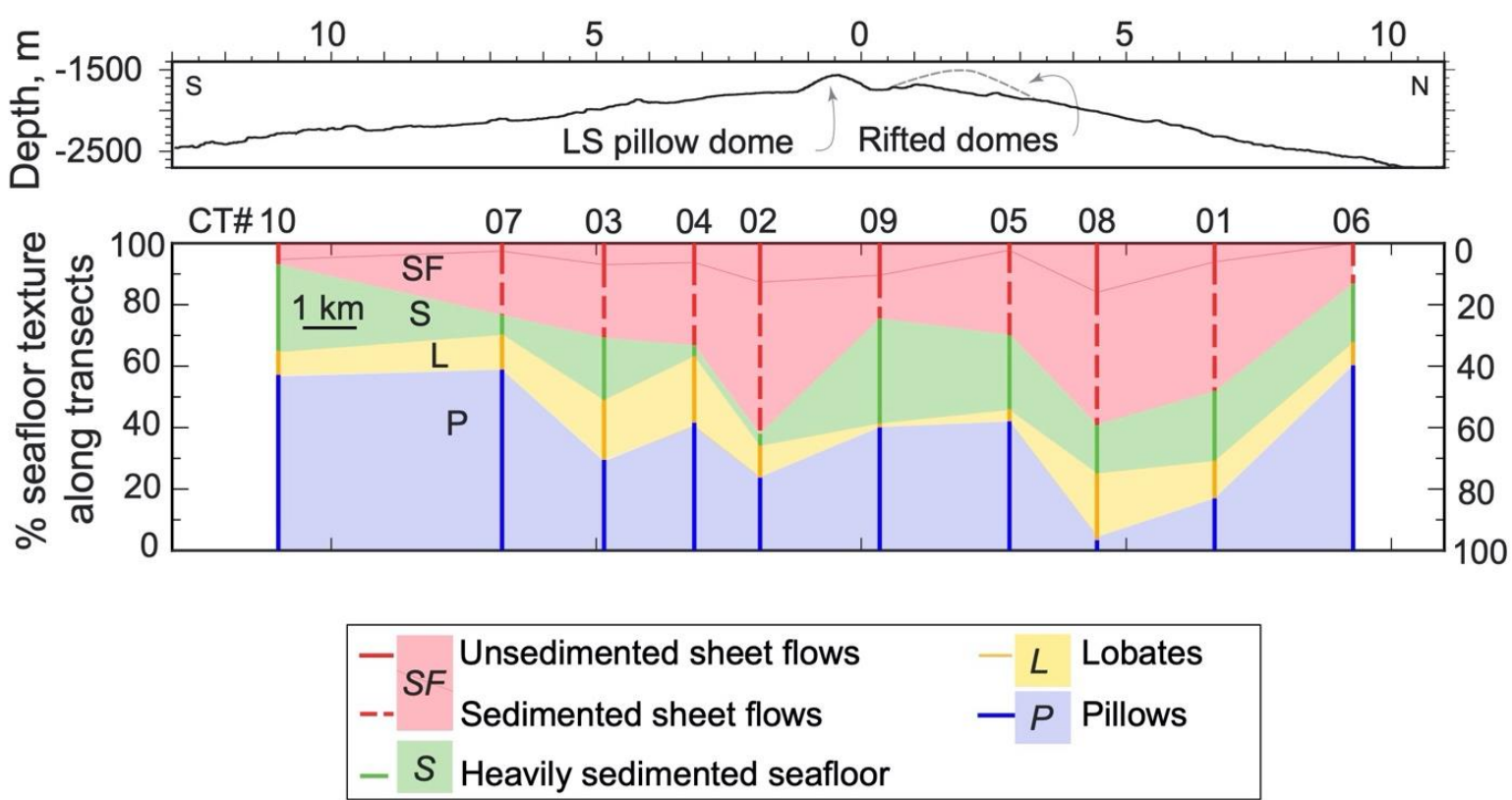

b)

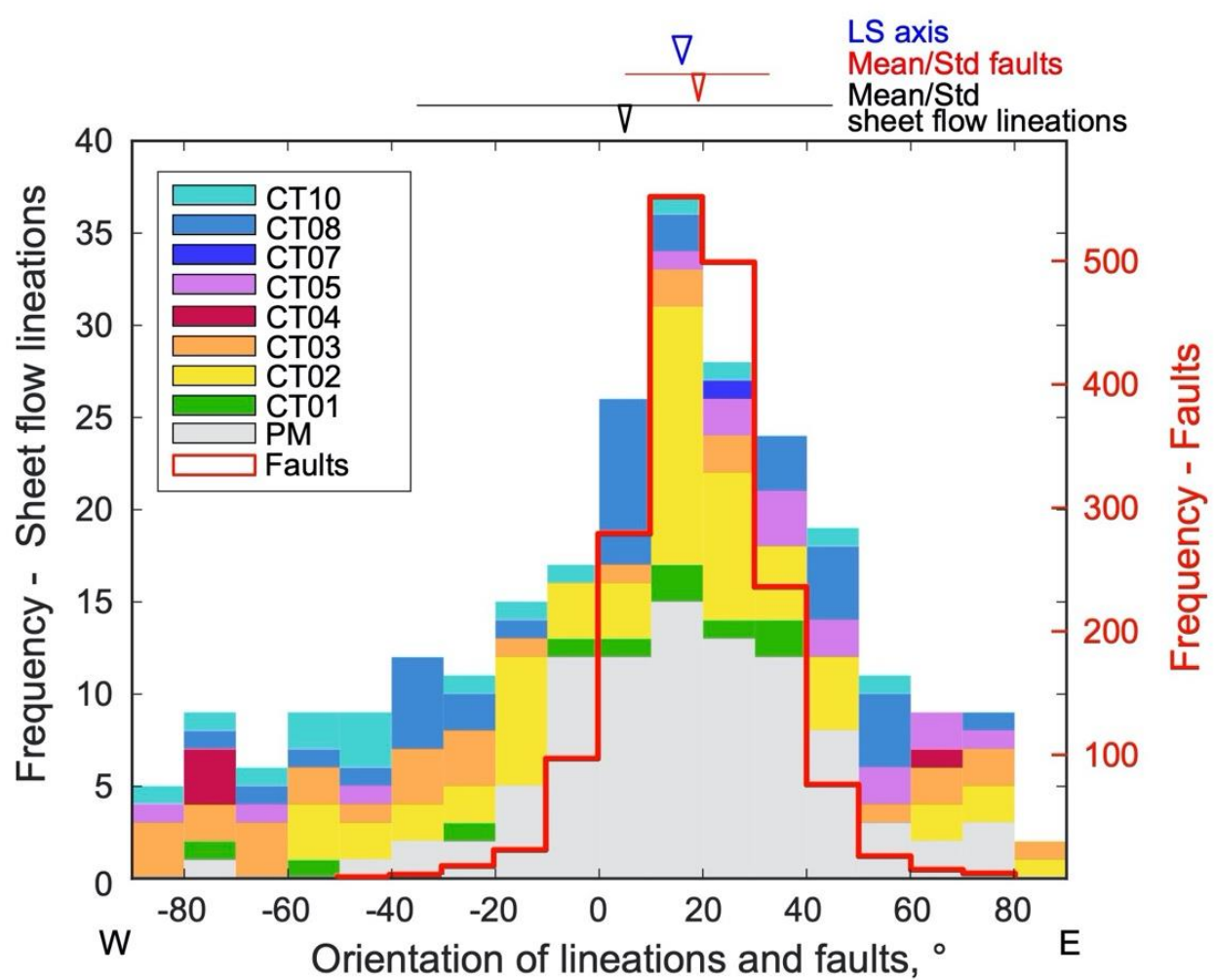


$749 \quad$ Figure 7

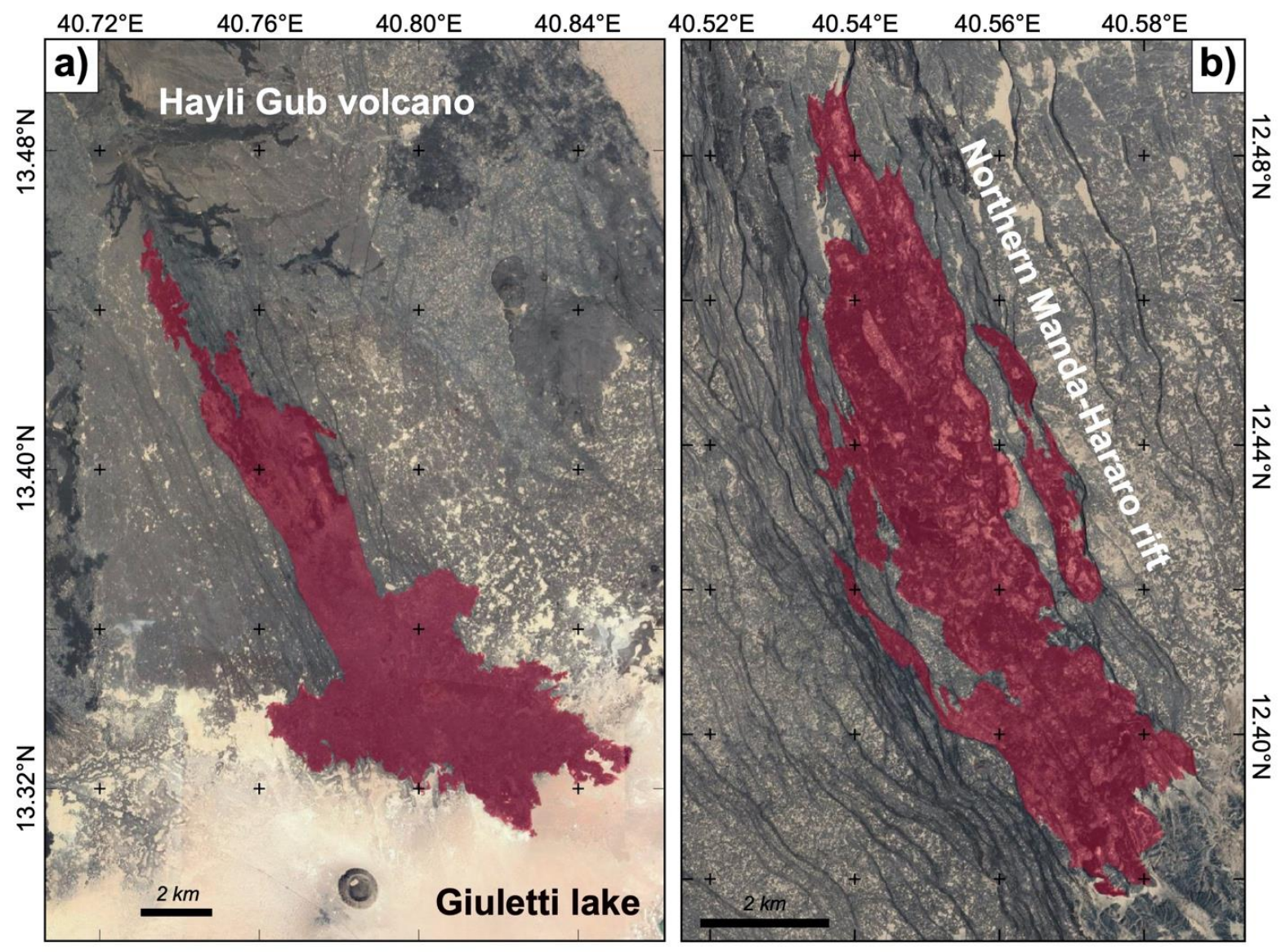


Figure 8

a)

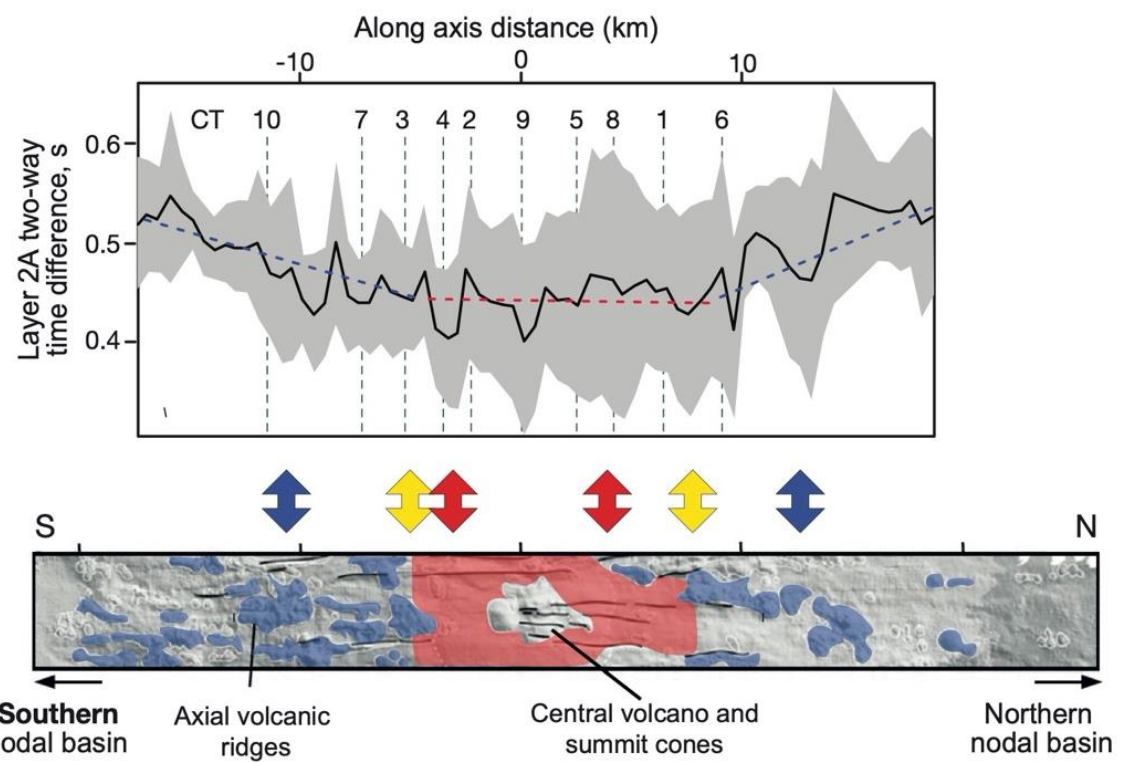

c)

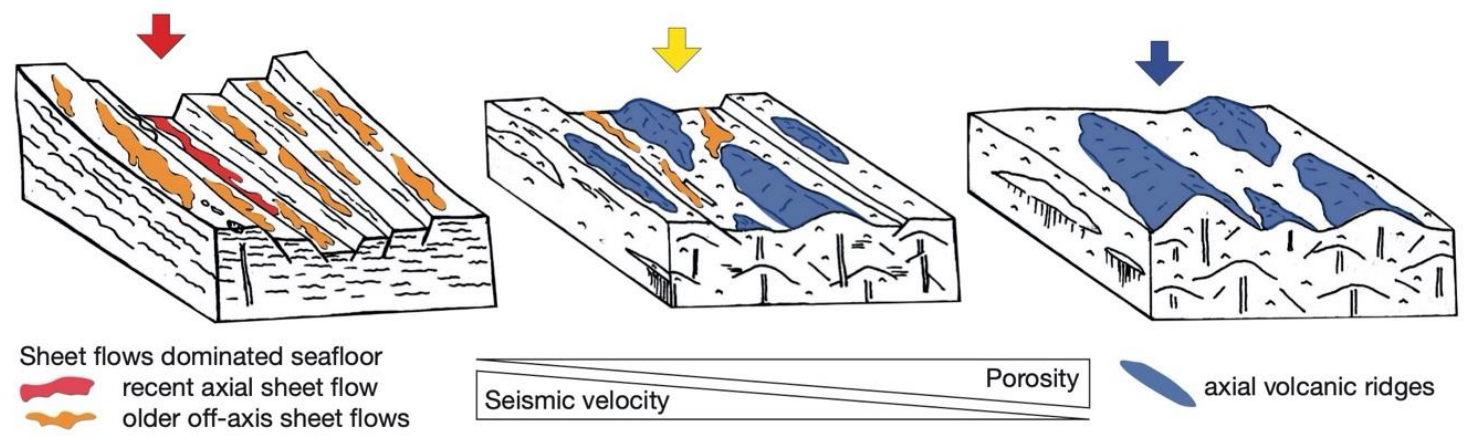




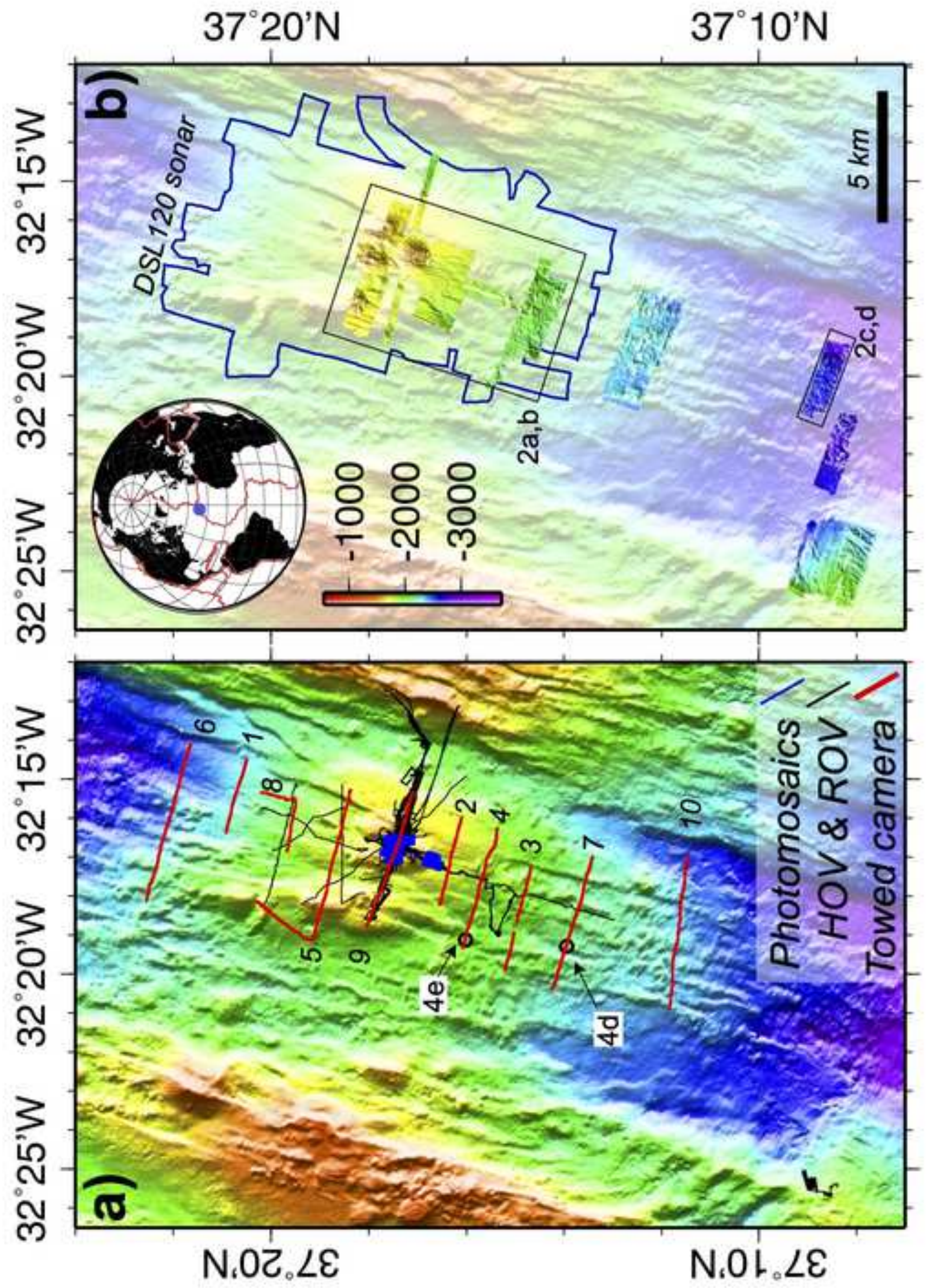




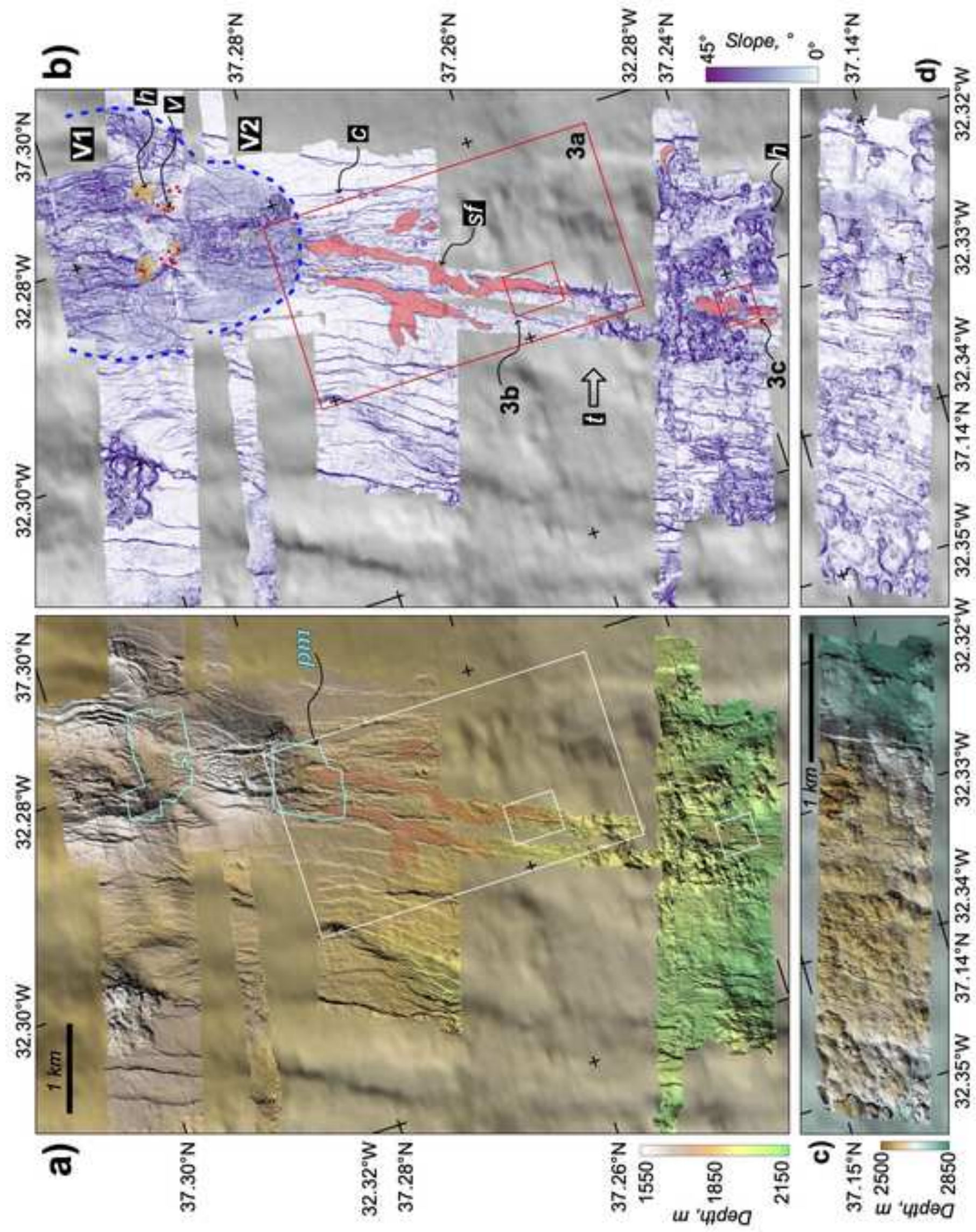



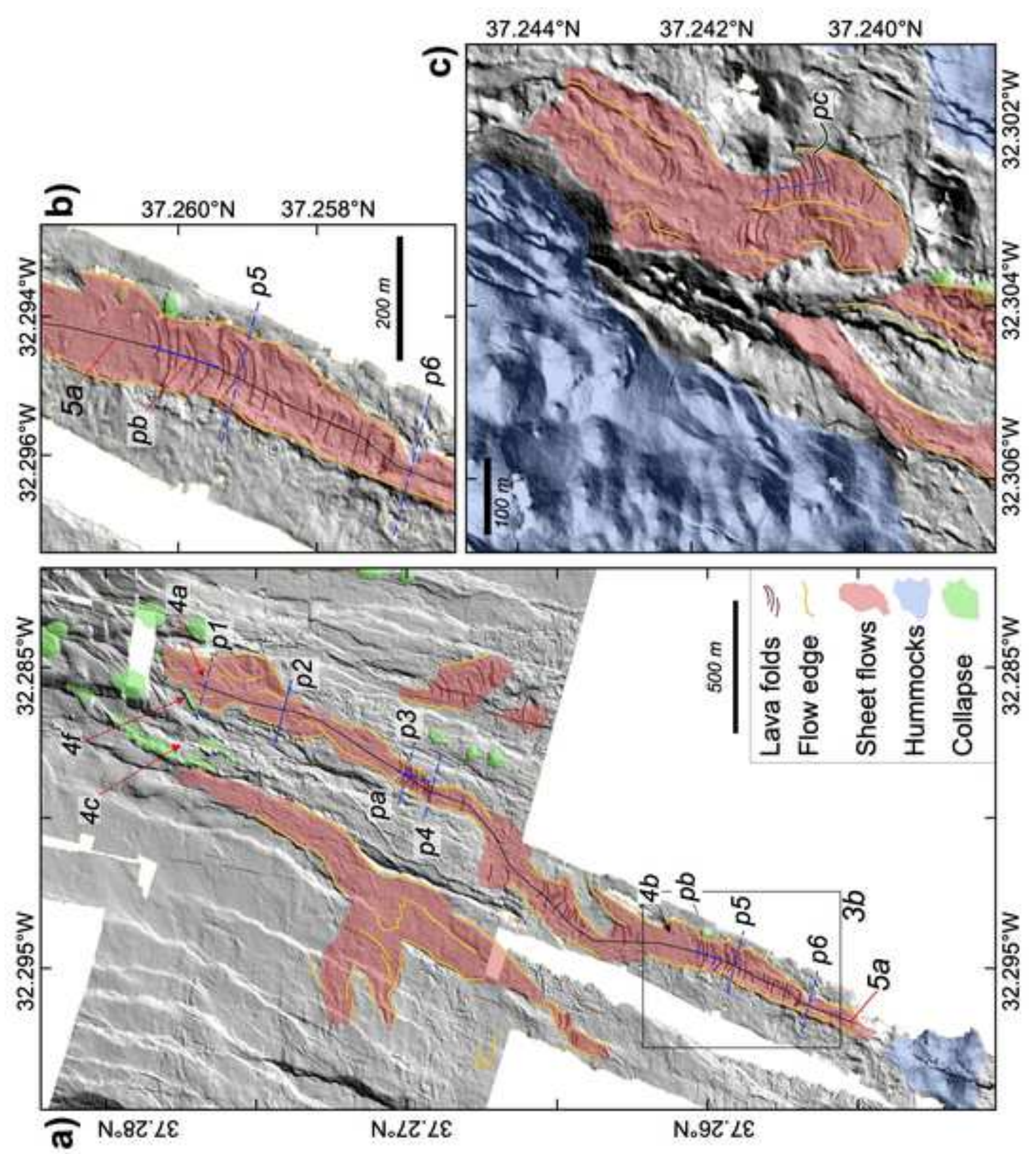

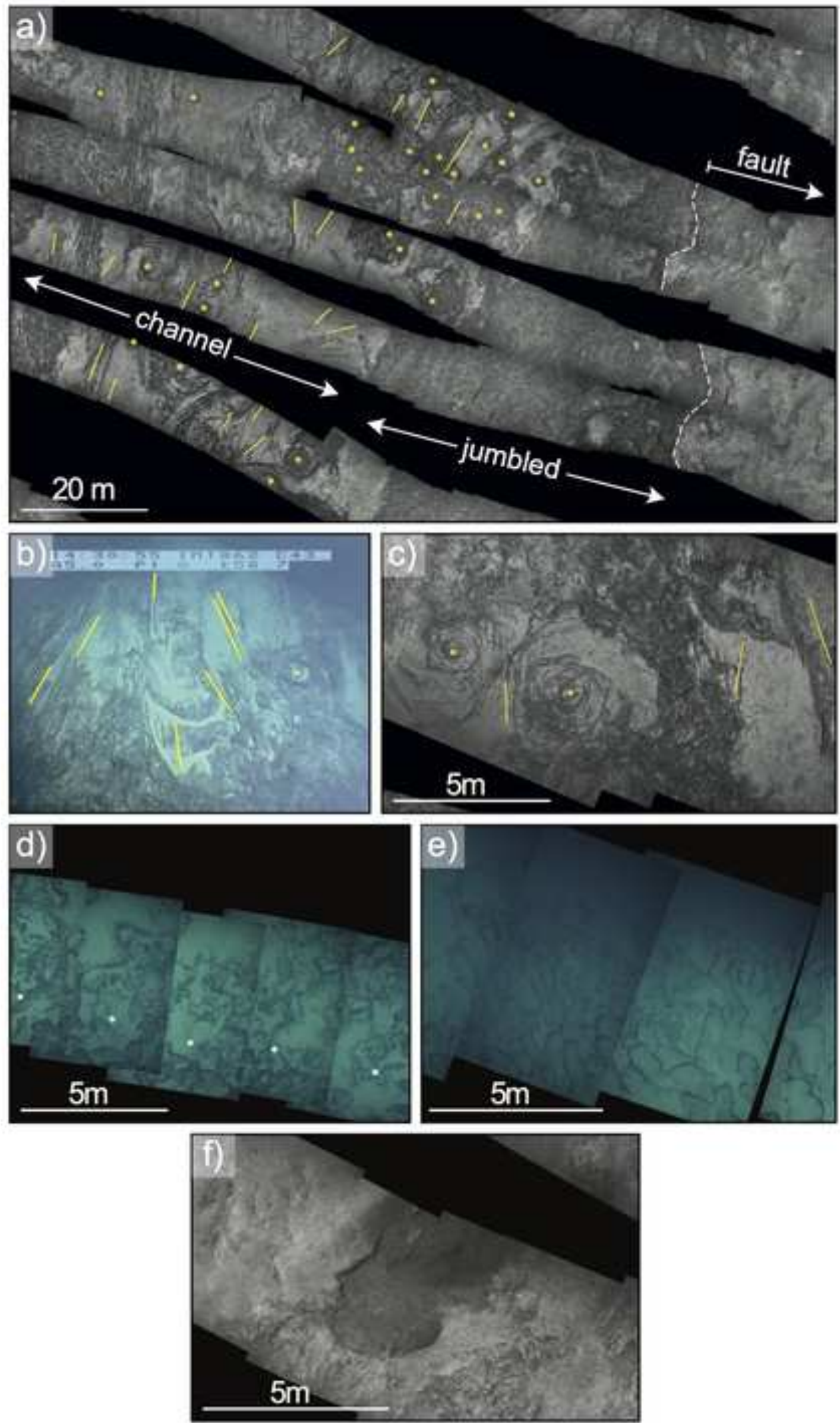

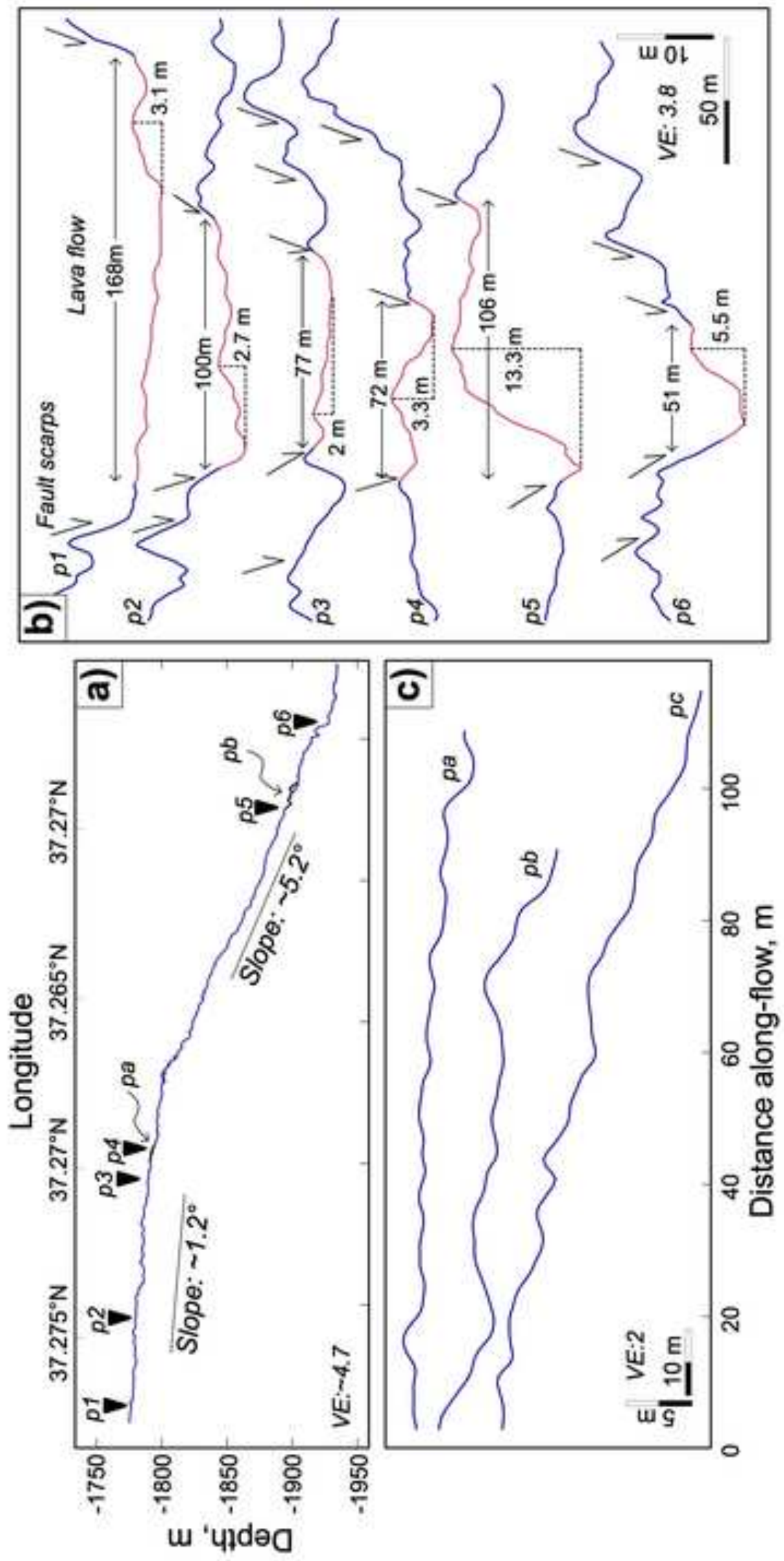

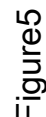


a)

Distance from segment center, $\mathrm{km}$
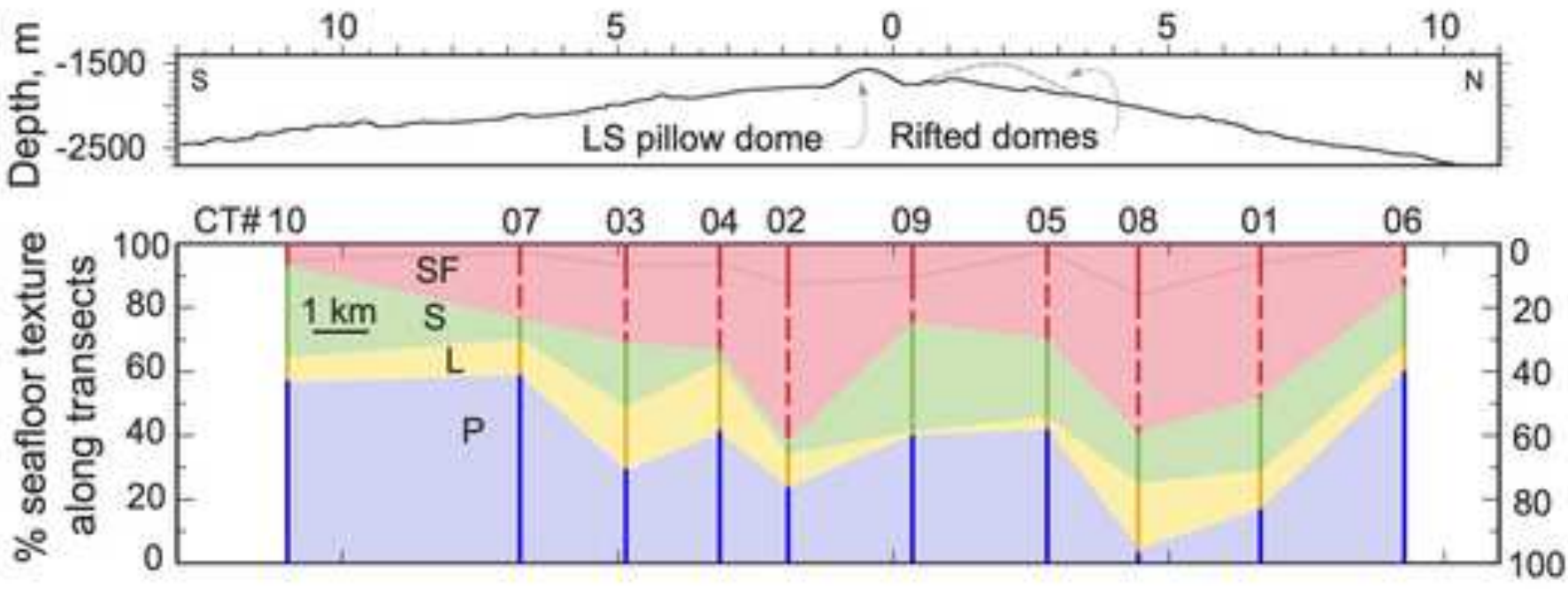

$$
\begin{aligned}
& \text { - SF Unsedimented sheet flows }-L \text { Lobates } \\
& \text {-. Sedimented sheet flows } \quad-P \text { Pillows } \\
& -S \text { Heavily sedimented seafloor }
\end{aligned}
$$

b)

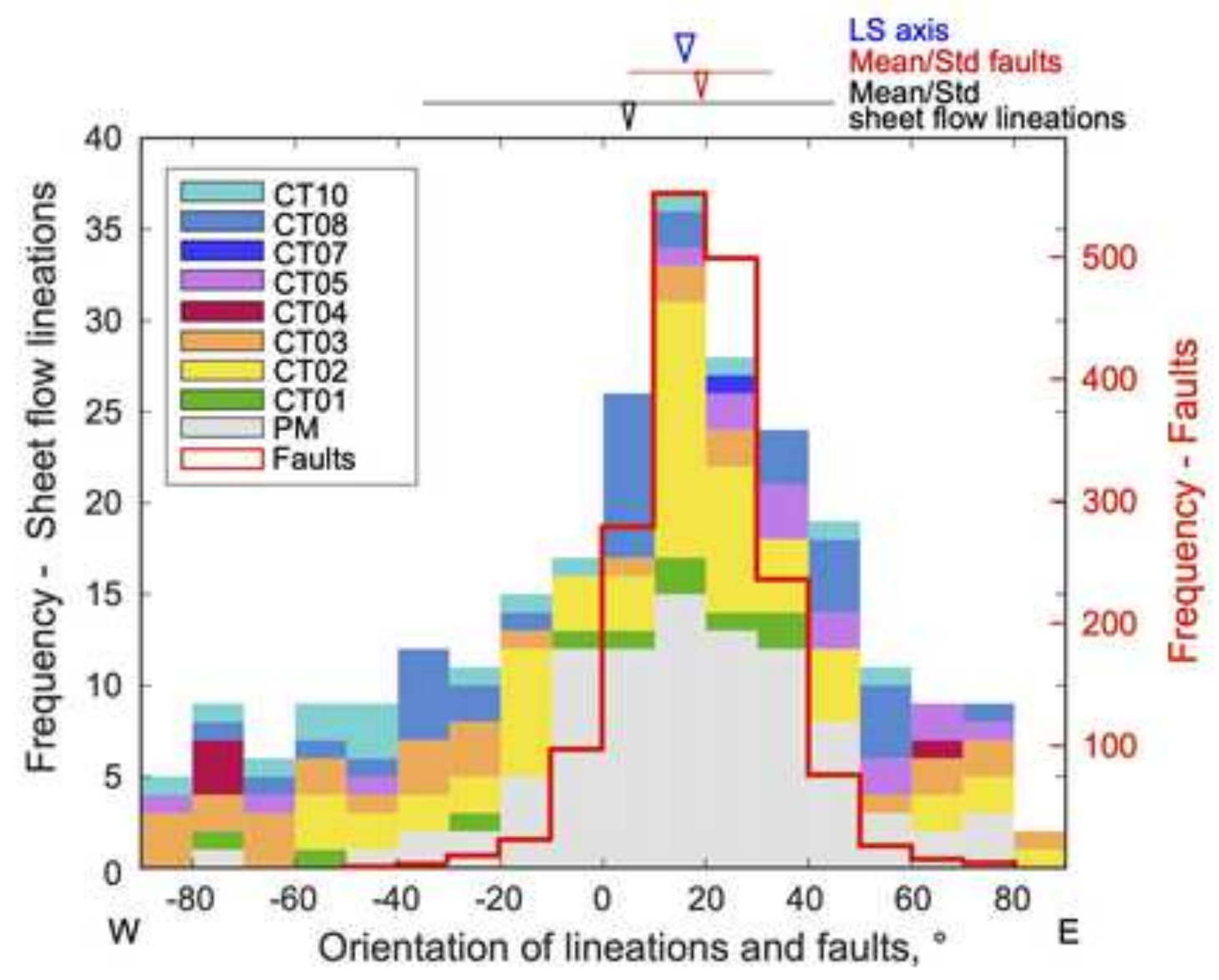



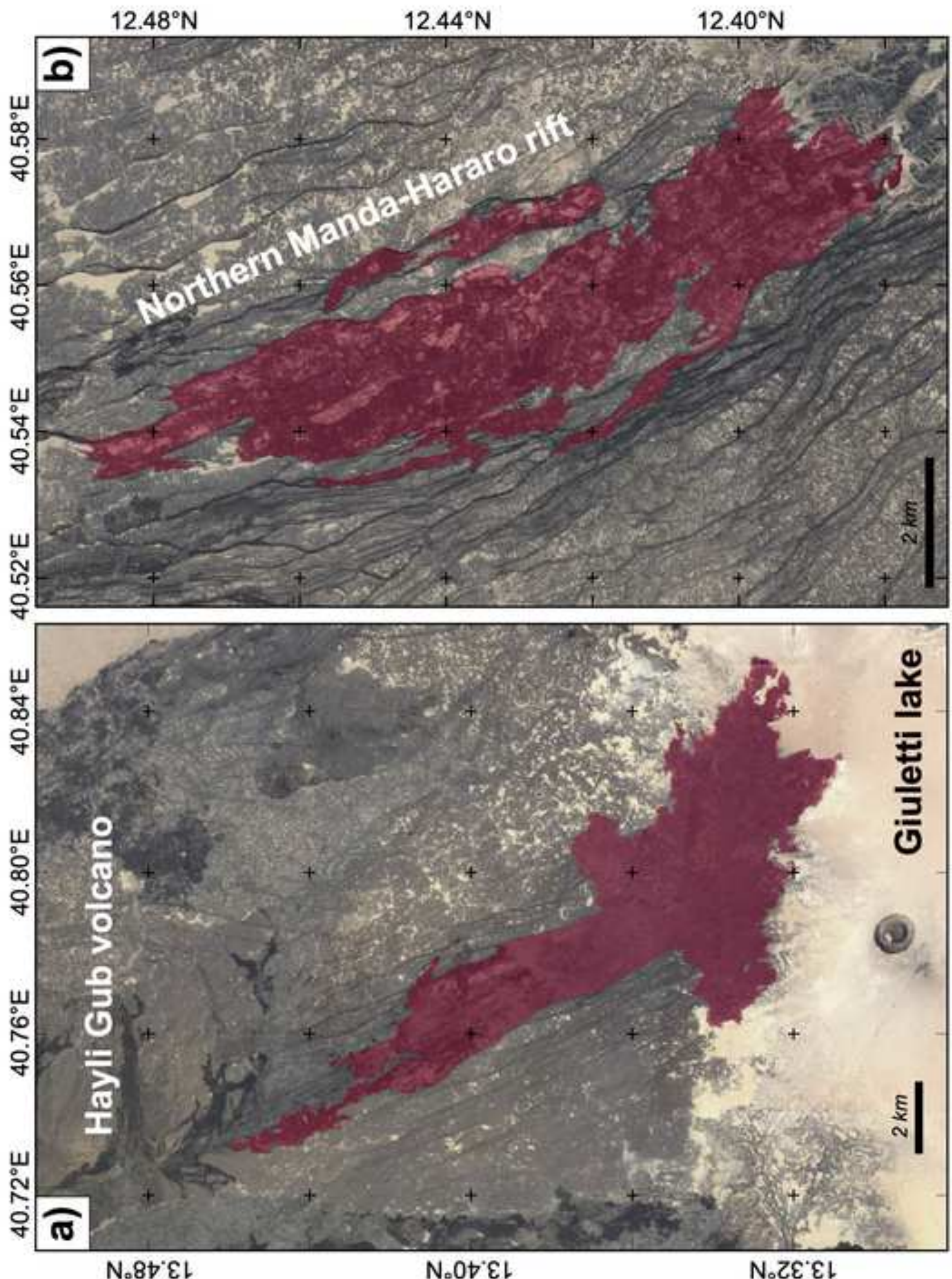

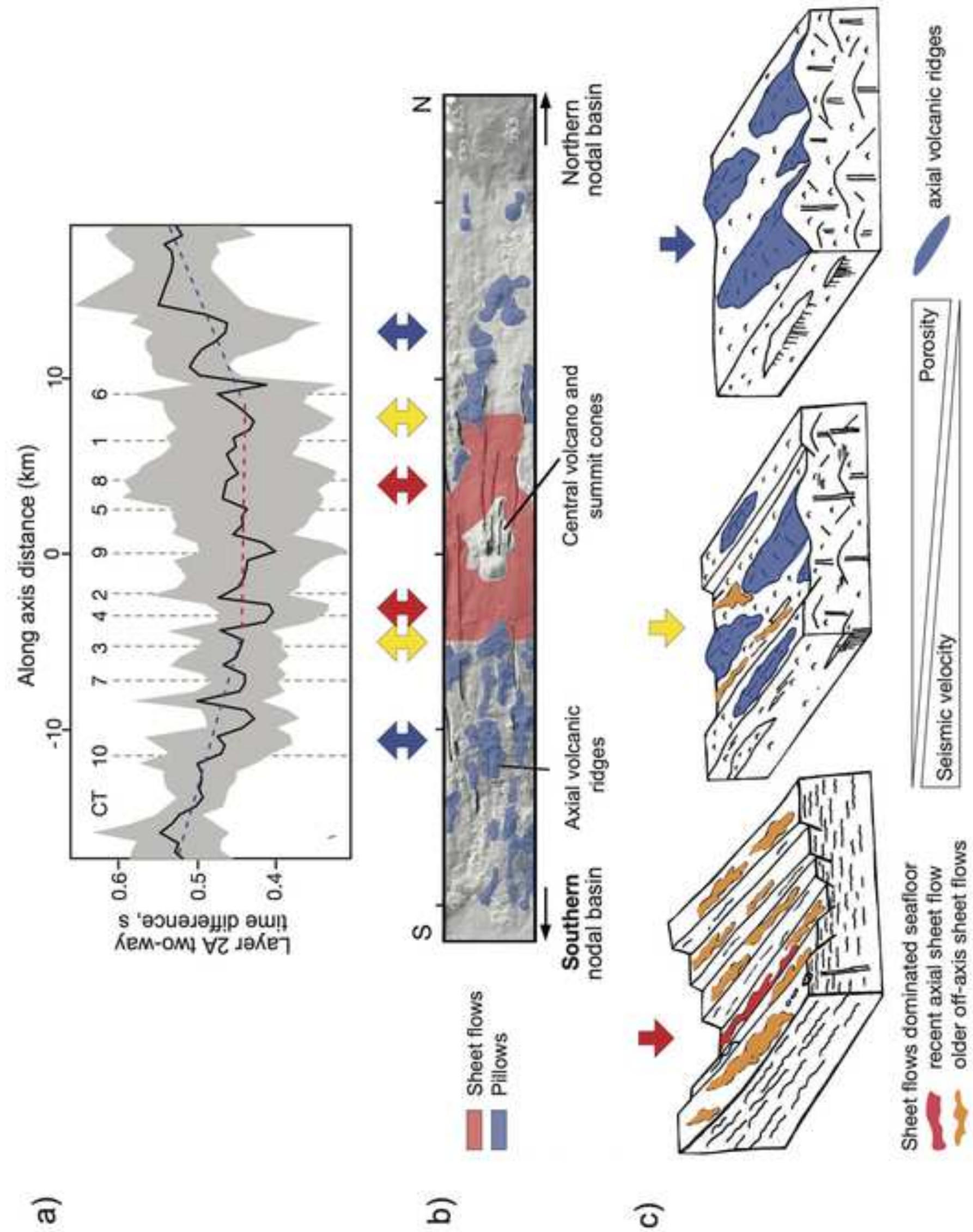

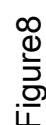




\title{
Extrusive upper crust formation at slow-spreading ridges: fault steering of lava flows and magma supply gradients
}

\author{
C. Gini ${ }^{1,3}$, J. Escartín², M. Cannat ${ }^{3} \&$ T. Barreyre ${ }^{4}$
}

${ }^{1}$ Dept. of Earth Sciences, Memorial University of Newfoundland, St. John's, Canada

${ }^{2}$ Laboratoire de Géologie, UMR 8538, Ecole Normale Supérieure, PSL Research University, CNRS, Paris, France

${ }^{3}$ Université de Paris, Institut de Physique du Globe de Paris, CNRS, Paris, France

${ }^{4}$ Centre for Deep Sea Research, University Bergen, Bergen, Norway

Supplementary information

1. Supplementary figures
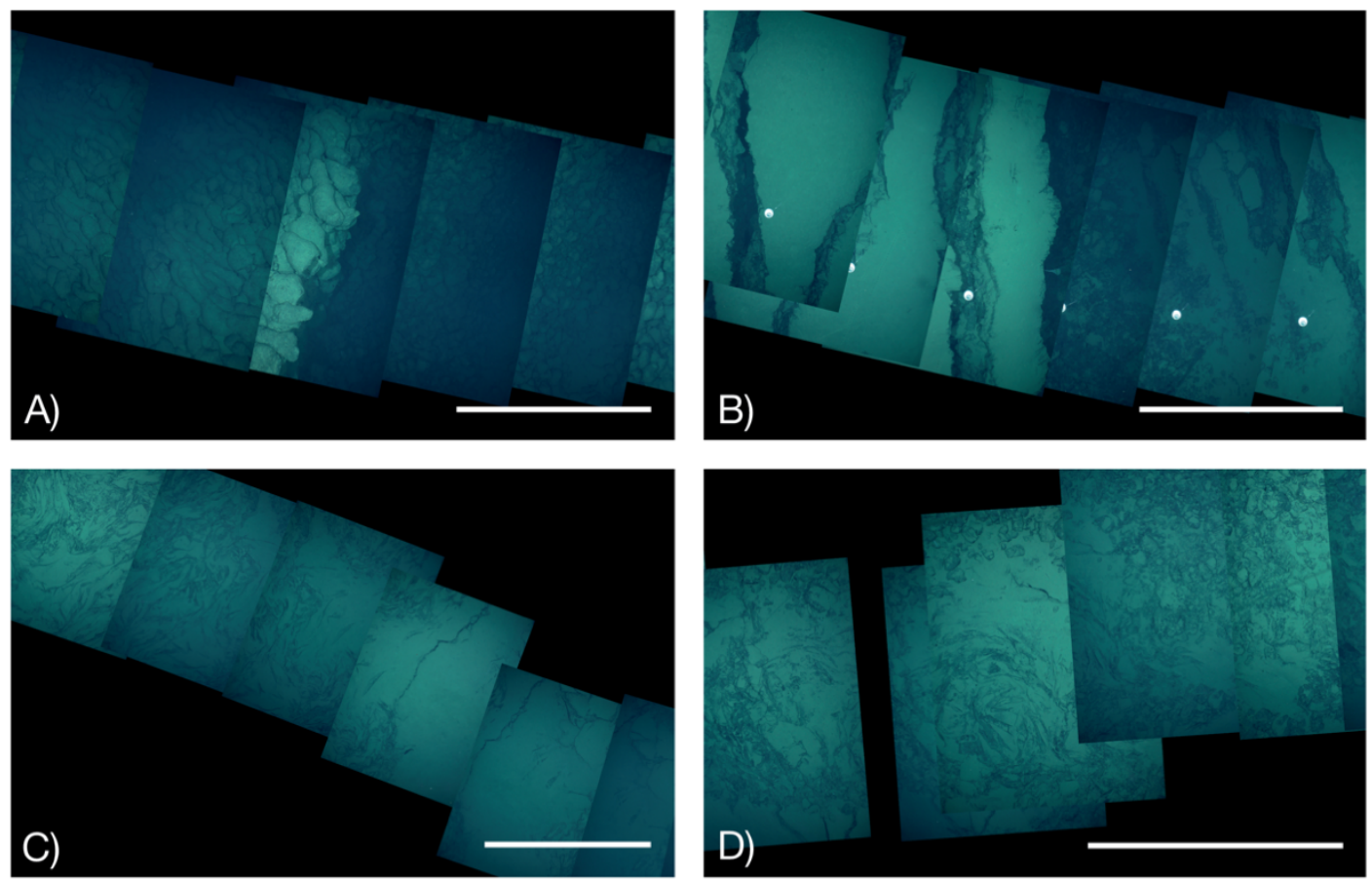

Supplementary Figure S1. A) Fissure cross-cutting sedimented pillows (CT07, N $37.22699^{\circ} \mathrm{N} 32.29971^{\circ} \mathrm{W}$ ). B) Fissure on sedimented seafloor (no volcanic texture visible) but showing underlying sheeted flows $\left(\mathrm{CT} 07,37.23124^{\circ} \mathrm{N} 32.31598^{\circ} \mathrm{W}\right)$. C) Sheeted flow and hackly margin, found off-axis and partially sedimented (CT10, $\left.\left.37.19636^{\circ} \mathrm{N} 32.33184^{\circ} \mathrm{W}\right) . \mathrm{D}\right)$ Sedimented sheet flow with lava whorls $\left(\mathrm{CT10}, 37.19630^{\circ} \mathrm{N} 32.33115^{\circ} \mathrm{W}\right)$. White scale bar is $\sim 10 \mathrm{~m}$. 

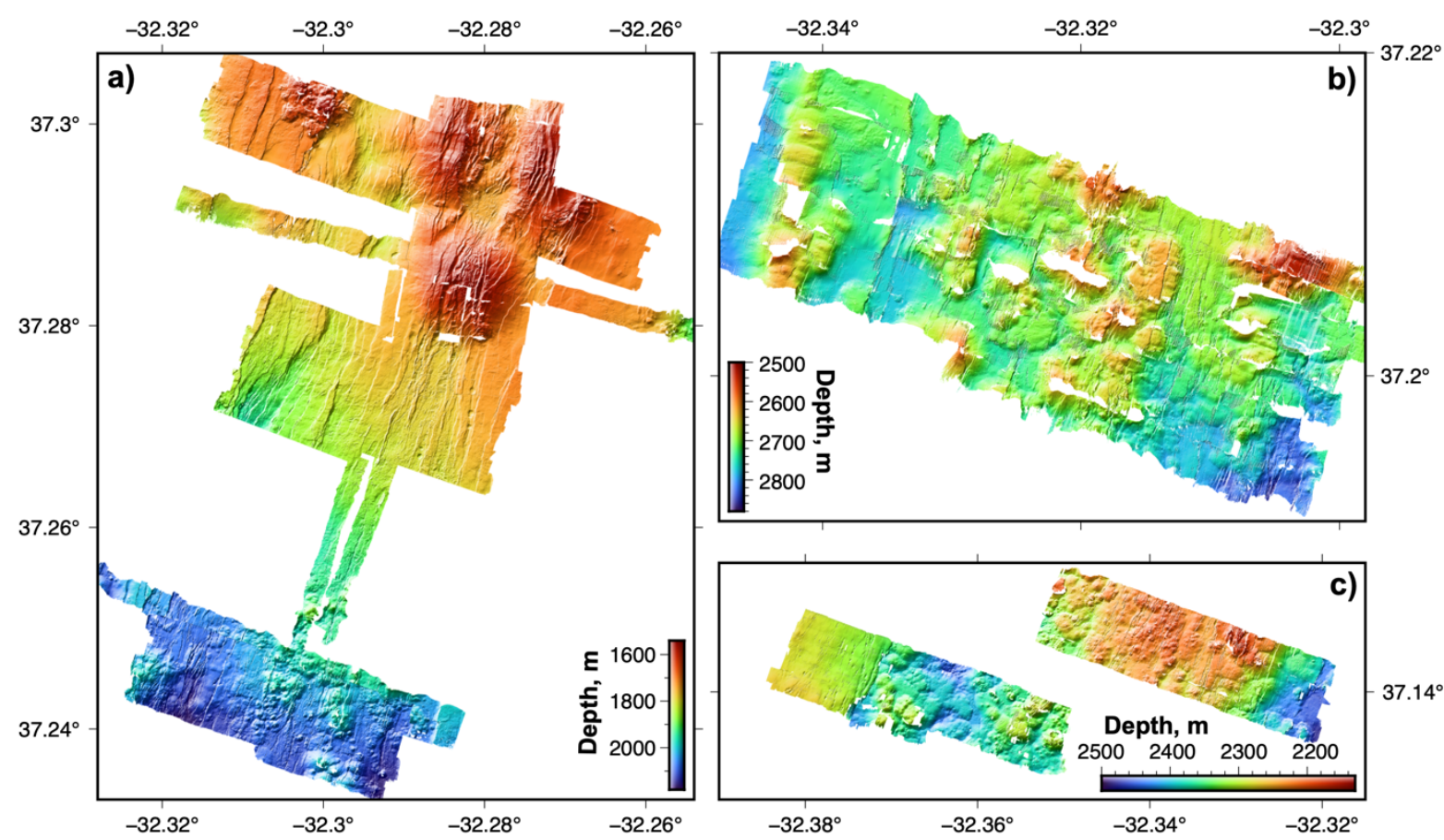

Figure S2. Bathymetry maps acquired during ROV Victor and AUV AsterX surveys along the Lucky Strike rift valley floor (see location in Figure 1).
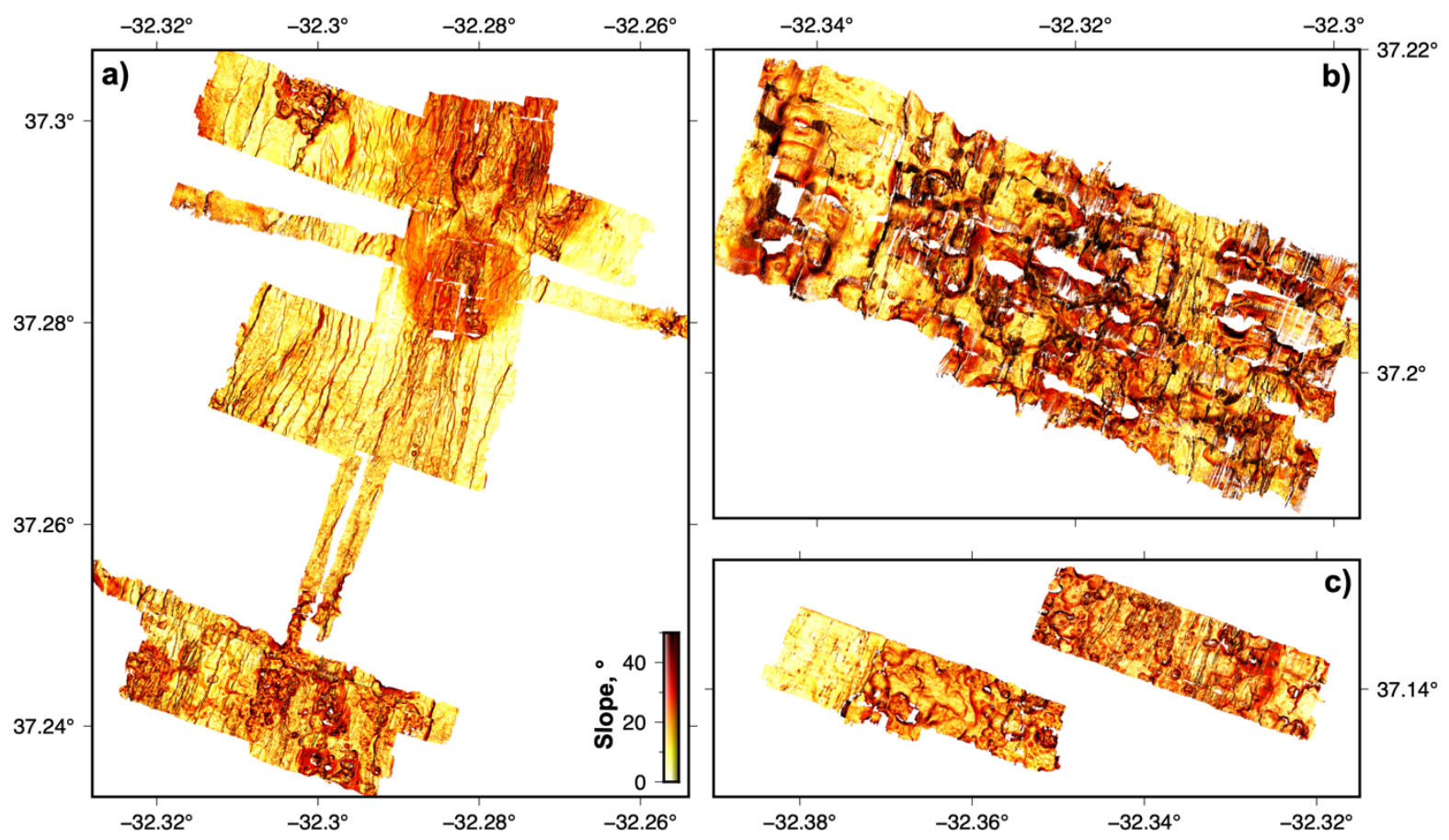

Figure S3. Slope maps of the bathymetry shown in Figure S2, clearly revealing the differences in seafloor texture between zones dominated by lava sheet flows (north part of a) and areas dominated by hummocks and axial volcanic ridges (south of $a$ and $b, c$ ). 


\section{Data used in this study}

Data were acquired over several cruises as follows:

1) During the 1996 KN145-19 "Lustre'96" cruise (http://www.marinegeo.org/tools/ entry/KN145-19) high-resolution side-scan sonar data were acquired with the DSL120 deep-towed sonar system. Black-and white vertical electronic still camera seafloor imagery was acquired with the deep-towed Argo-II camera system, in addition to observations during HOV Alvin dives.

2) During the 2006 Graviluck cruise (doi:10.17600/6010110) vertical color seafloor digital imagery were acquired with the deep-towed TOWCAM system, while HOV Nautile acquired video imagery and recorded geological observations during dives.

Photomosaics for these camera tows were generated from vehicle navigation (layback and depth) and attitude (heading and altitude), and assuming a flat bottom. Images were not matched nor renavigated owing to limited or no overlap along track.

Photomosaics have been tiled as geotiffs, and are publicly available: doi: $10.17882 / 80790$

3) During the MOMARETO, MOMAR'08-Leg1 and Bathyluck cruises in 2006, 2008 and 2009 (dois 10.17600/6030130, 10.17600/8010110 and 10.17600/9030040, respectively), near-bottom, high-resolution bathymetry data were acquired with a multibeam system mounted on the ROV VICTOR 6000 and the AUV AsterX. ROV Victor also conducted geological surveys and observations, in addition to imagery surveys, using the OTUS black and white camera vertically mounted, to obtain photomosaics of the seafloor in 2008 and 2009. Open access links to bathymetry and photomosaics are indicated below. 
Data publicly available and used in this paper include microbathymetry and seafloor photomosaics:

High-resolution bathymetry. Near-bottom multibeam bathymetry data were processed post-cruise (cleaning, filtering, gridding), to obtain bathymetry grids at resolutions of either $1 \mathrm{~m}$ (surveys along the LS segment) or $0.50 \mathrm{~m}$ (survey at segment center acquired during photomosaic survey). The AUV or ROV was flown at $\sim 70 \mathrm{~m}$ in average (varying between 50 to $100 \mathrm{~m}$ ) for surveys with a resolution of $1 \mathrm{~m}$ per grid, and $\sim 10 \mathrm{~m}$ for the surveys conducted in combination with optical imagery, and gridded at $0.5 \mathrm{~m}$. Grids from different dives were manually shifted and adjusted to combine them into a single one in the central part of the segment (See Supplementary Figure S2a). Details of resulting grids and processing are partially published elsewhere (Escartín et al., 2015). Here we release the full set of near-bottom, AUV and ROV bathymetry grids: doi: 10.17882 / 80574

Seafloor imagery and photomosaics. Vertically acquired imagery during ROV VICTOR6000 surveys and TOWCAM tracks were processed by the Girona University for illumination corrections, renavigation, and mosaicing. VICTOR survey processing included blending of imagery to obtain seamless photomosaics that facilitate their interpretation (e.g., Barreyre et al., 2012), while imagery from tracks were photomosaiced solely on navigation and altitude information (e.g., Escartín et al., 2008), with no blending; these mosaics provide information on scale and orientation of structures, even if images are not matched and blended locally. Details on mosaicing procedures are described elsewhere (e.g., Escartín et al., 2008; Prados et al., 2012; Barreyre et al., 2012).

The 2008 photomosaic is publicly available as a series of GEOTIF tiles at doi: $10.17882 / 77449$

The 2009 photomosaic is publicly available as a series of GEOTIF tiles at doi: $10.17882 / 80447$

The photomosaic from the Lustre'1996 cruise (Escartín et al., 2008) is publicly available at: http: / / www.marine-geo.org/tools / search / Files.php?data_set_uid=6138 


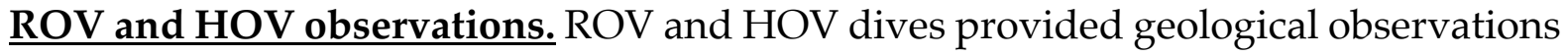
throughout the study area during different dives. All imagery available to us (still images and video) was examined to extract relevant geological observations (types of lava flows, orientation of structures, sedimentation, etc.). The observations of this study complemented those reported by the different science parties in each of the cruises listed above.

Video imagery along ROV Victor and HOV Nautile tracks from the 2006, 2008 and 2009 cruises can be made available upon request to J. Escartín.

Acoustic backscatter: Acoustic backscatter data acquired with the deep-towed DSL120 sonar was used to provide a broader context to the near-bottom bathymetry data, and to extrapolate observations among survey areas, as it has a more continuous coverage. Details on sonar data acquisition and processing are given elsewhere (Scheirer et al., 2000; Humphris et el., 2002; Escartín et al., 2014), and the gridded sonar data with a resolution of $10 \mathrm{~m}$ are publicly available at: http://www.marinegeo.org / tools / search / DataSets.php?data_set_uids=7527,21460

Here we used this processed dataset, as well as its published tectonic interpretation (Escartín et al., 2014) for fault orientations.

Identification and quantification of seafloor textures and flow lineations. TowCam photomosaics were used for identification and classification of lava flow morphologies and sediment presence or absence, and for quantification of the resulting abundance of classes. For camera tows, the dominant seafloor texture was visually defined every $50 \mathrm{~m}$ along-track, identifying at the same the transitions, to define along-track segments. Each segment was attributed then a seafloor texture. Calculation of proportions along each TowCam track (Figure 6a) is then derived from the cumulative length of segments for each seafloor texture, normalized by the total length of each camera transect. No quantification of lava textures was done on the ROV OTUS photomosaics. 
Where sheet flows with lineations were identified along the TowCam tracks, the most prominent structures where digitized to calculate their orientations. Due to the narrow across-track coverage of the seafloor, of approximately $10 \mathrm{~m}$, we were not able to map the full extent and limits of each flow. Hence lineations provide a flow direction locally, that we assume to be representative of the overall lava flow direction, that is dominantly along-axis (Figure 6b).

\section{Supplementary Material References}

Ballu, V., (2006) GRAVILUCK cruise, RV L'Atalante, https: / / doi.org/10.17600/6010110

Barreyre, T., Escartín, J., Garcia, R., Cannat, M., Mittelstaedt, E., and Prados, R., 2012, Structure, temporal evolution, and heat flux estimates from the Lucky Strike deep-sea hydrothermal field derived from seafloor image mosaics: Geochemistry, Geophysics, Geosystems, v. 13, no. 4, p. n/a-n/a, doi: 10.1029/2011GC003990.

Cannat, M., (1998) SUDACORES cruise, RV L'Atalante, https:/ / doi.org/10.17600/98010080

Crawford, W.C., Singh, S.C., (2005) SISMOMAR cruise, RV L'Atalante, https: / / doi.org/10.17600/5010040

Dyment, J., (2008) MOMAR2008-LEG2 cruise, RV L'Atalante, https: / / doi.org/10.17600/ 8010140

Escartín, J., García, R., Delaunoy, O., Ferrer, J., Gracias, N., Elibol, A., Cufi, X., Neumann, L., Fornari, D.J., Humphris, S.E., Renard, J., 2008. Globally aligned photomosaic of the Lucky Strike hydrothermal vent field (Mid-Atlantic Ridge, $\left.37^{\circ} 18.5^{\prime} \mathrm{N}\right)$ : Release of georeferenced data, mosaic construction, and viewing software. Geochemistry, Geophys. Geosystems 9, n/a--n/a. https: / / doi.org/10.1029/2008GC002204

Escartín, J., (2008) MOMAR2008-LEG1 cruise, RV L'Atalante, https:// doi.org/10.17600/8010110 
Escartín, J., Barreyre, T., Gracias, N., Garcia, R., (2008). Lucky Strike hydrothermal field (Mid-Atlantic Ridge at $237.25^{\circ} \mathrm{N}$ ) - seafloor photomosaic (MOMAR08-Leg 1 cruise): 1-cm resolution black-and-white geotiffs (UTM zone 25 projection). SEANOE. https: / / doi.org/10.17882/77449

Escartín, J., Cannat, M., (2009) BATHYLUCK 2009 cruise, RV Pourquoi pas ? https:// doi.org/10.17600/9030040

Escartín, J., Cannat, M., (2009). Bathyluck'09 Cruise (Lucky Strike). Horta-Horta (Portugal), August 31st - September 29th 2009. NO PourQuoi Pas ? - ROV Victor 6000 - AUV AsterX. https: / / doi.org/10.13155/47147

Escartín, J., (2009). EWAN hydrothermal site (Mid-Atlantic Ridge south of Lucky Strike): Seafloor photomosaic (black and white, VICTOR 6000, 2009). SEANOE. https: / / doi.org/10.17882/77405

Escartín, J., Fornari, D. and Humphris, S., (2014). DSL120 Sidescan Sonar Grids of the Lucky Strike Segment of the Mid-Atlantic Ridge from the R/V Knorr expedition KN145-19 (1996). IEDA. doi:10.1594/IEDA/321460

Escartín, J., Barreyre, T., Cannat, M., Garcia, R., Gracias, N., Deschamps, A., Salocchi, A., Sarradin, P.-M., Ballu, V., 2015. Hydrothermal activity along the slowspreading Lucky Strike ridge segment (Mid-Atlantic Ridge): Distribution, heatflux, and geological controls. Earth Planet. Sci. Lett. 431, 173-185. https: / / doi.org/10.1016/j.eps1.2015.09.025

Escartín, J., Cannat, M., Deschamps, A., (2021). Microbathymetry from AUV and ROV Surveys (MOMARETO'06, MOMAR'08-Leg1 and BATHYLUCK'09 cruises) along the Lucky Strike ridge segment (Mid Atlantic Ridge). SEANOE. https:// doi.org/10.17882/80574

Humphris, S.E., Fornari, D.J., Scheirer, D.S., German, C.R., Parson, L.M., 2002. Geotectonic setting of hydrothermal activity on the summit of Lucky Strike Seamount ( $37^{\circ} 17^{\prime} \mathrm{N}$, Mid-Atlantic Ridge). Geochemistry, Geophys. Geosystems 3, 1-25. https: / / doi.org/10.1029/2001GC000284 
Prados, R., Garcia, R., Gracias, N., Escartín, J., Neumann, L., 2012. A novel blending technique for underwater gigamosaicing. IEEE J. Ocean. Eng. 37, 10.1109/JOE.2012.2204152.

Sarradin, P-M., Sarrazin, J., (2006) MOMARETO cruise, RV Pourquoi pas ?, https: / / doi.org/10.17600/6030130

Scheirer, D.S., Fornari, D.J., Humphris, S.E., Lerner, S., 2000. High-resolution seafloor mapping using the DSL-120 sonar system: Quantitative assessment of sidescan and phase-bathymetry data from the Lucky Strike segment of the Mid-Atlantic Ridge. Mar. Geophys. Res. 21, 121-142. https: / / doi.org/10.1023/ A:1004701429848 